\title{
Earthquake Vulnerability Mapping using Binary Comparison Matrix and Analytical Hierarchical Process (AHP) in Lalmatia, Dhaka
}

\section{Tanzila Aktar Shawon}

Jahangirnagar University

Mohammad Mizanur Rahman ( $\nabla$ mizanurp@juniv.edu )

Jahangirnagar University

Md. Zibon Ahmmed

Jahangirnagar University

Md. Akter Mahmud

Jahangirnagar University

\section{Research Article}

Keywords: Analytical Hierarchy Process, Earthquake, Retrofit, Social Appraisal, Vulnerability

Posted Date: April 14th, 2021

DOI: https://doi.org/10.21203/rs.3.rs-374325/v1

License: (c) (i) This work is licensed under a Creative Commons Attribution 4.0 International License. Read Full License 


\title{
Earthquake Vulnerability Mapping using Binary Comparison Matrix and Analytical Hierarchical Process (AHP) in Lalmatia, Dhaka
}

\author{
Mst. Tanzila Aktar Shawon ${ }^{1}$ \\ Mohammad Mizanur Rahman ${ }^{2}$ \\ Md. Zibon Ahmmed ${ }^{3}$ \\ Akter Mahmud ${ }^{4}$
}

${ }^{1}$ Postgraduate Researcher, Department of Urban and Regional Planning, Jahangirnagar University, Savar, Dhaka - 1342, Bangladesh. Email: shawonurp17ju44@gmail.com

${ }^{2}$ Assistant Professor, Department of Urban and Regional Planning, Jahangirnagar University, Savar, Dhaka-1342, Bangladesh. Email: mizanurp@juniv.edu.com

${ }^{3}$ Research Assistant, Department of Geography and Environment, Jahangirnagar University, Savar, Dhaka - 1342, Bangladesh. Email: zibonahmmed@gmail.com

4 Professor, Department of Urban and Regional Planning, Jahangirnagar University, Savar, Dhaka - 1342, Bangladesh. Email: aktermahmud@yahoo.com 


\title{
Earthquake Vulnerability Mapping using Binary Comparison Matrix and Analytical Hierarchical Process (AHP) in Lalmatia, Dhaka
}

\begin{abstract}
From the historical records, geological evident and recent trends in earthquake, it is evident that Bangladesh is in a high-risk zone of earthquake hazard. The recent results of the CDMP, if a huge earthquake greater or equal to seven magnitude happened in this country, would lead to a serious human tragedy due to the defective structure. In Lalmatia, Dhaka study area there are various types of structures as like as RCC, masonry, semi-pucca etc. and the area has different old and newly filled soil development. This study considered the characteristics of RCC building elements and their behaviors to assess the risk against earthquake vulnerability in Lalmatia using the Turkish method. Next building vulnerability from Turkish Method used as one total vulnerability factor. In the method of this research, a pair wise comparison matrix for a numerical relationship between two elements and the Analytical Hierarchical Process (AHP) model has been applied to decide in weight and to get rank of the vulnerability factors. By weighted sum vector among the six factors and calculating vulnerability index (VI), the overall vulnerability were identified in Lalmatia. Using Geographic Information System (GIS) and defining an ordinal scale of calculated result, the vulnerability status of single buildings of the study area is presented here. This research tells that $8.23 \%$ buildings are highly vulnerable and $14.24 \%$ buildings are moderately vulnerable to earthquake. About $77.53 \%$ buildings are less vulnerable. As the study area is in a major urban center (Dhaka City), the scenario of unplanned urbanization increases the overall vulnerability to higher scale.
\end{abstract}

Key Words: Analytical Hierarchy Process, Earthquake, Retrofit, Social Appraisal, Vulnerability.

\section{Introduction}

Dhaka with estimated population in 2020 is roughly 2.1 million (UN, 2020) and density of population is 44,500 per sq.km. (UN Habitat, 2020) which is a muddy plain including of a shallow water table (Islam et al., 2010). Unplanned urbanization has been going on rapidly for the last few decades without appropriate planning. Consequently, fast urbanization has resulted in hasty population growth and unplanned building to accommodate Dhaka city dwellers. Dhaka is said as one of the 20 most risky cities in the world in the perspective of the earthquake risk and infrastructure protection disaster risk index (Ahmed and Ahmed, 2010). Though Bangladesh has not evidenced any serious damaged earthquake for more than 100 years but the unplanned situation of the infrastructure and the geological situation may happen that Bangladesh is at high risk of damaging earthquake in upcoming future (CDMP, 2009a, 2009b, 2009c).

Earthquake seismic problems faced by the undulating ground and cities (Choudhury 1993; Paul and Bhuiyan 2010; Rashed and Weeks 2003; Sarraz et al. 2015; Sattar et al. 2009; Ziauddin 2016) in Bangladesh (e.g., Chittagong and Dhaka city) and the problems are also enlarging the spatial vulnerability as like as movement of plate, neo-tectonic depression (Khan and Hoque, 2002), geological development (Alam et al., 2008) and weekend in earth structure (Hossain, 2014). The city with rapid population and unplanned urbanization (Hossain, 2014), without seismic capacity multi-storied buildings (Islam et al., 2016) and old aged building which is non-regulated with seismic capacity (Ansary and Ali 2004; Hossain 2014; Jahan et al. 2008; Kamal 2009; Reja 2008) also may added dangerous problems in earthquake. In Last 100 years Bangladesh and adjacent areas faced 1000 earthquakes taking a magnitude equal or more than 4 scale (Alam et al., 2011) and earthquakes are expected equivalent about $60 \%$ of total natural disaster in world (Agarwal and Shrikhande, 2007).

Without appropriate planning Dhaka is developing very fast and as a result we can see more incidents like the collapse of the Begunbari building on June 1, 2010. The buildings were built on wet land and in earthquake the soil liquefaction may happened on this building (Rahman, 2010). The Meteorological Department and BUET has identified about 90 earthquakes were occurred in Bangladesh through May 2007 to July 2008. Among the identified history of earthquakes, nine of which are above five on the Richter scale and $95 \%$ of which were within a radius of $600 \mathrm{~km}$ of Dhaka city (Ferdous and Rahman, 2015). CDMP (2009a, 2009b, 2009c) assessed that the Madhupur fault generates 7.5 Mw magnitude for Dhaka city. According to this assessment, out of total 3,26,000 
buildings, approximately 270,604 buildings will be at least moderately damaged which comprises over $89 \%$ of total building stock. Besides 238,164 buildings will be damaged outside restoration. Around 260,788 and 182,450 people will die respectively for an earthquake taking place at 2:00 AM and 2:00 PM. Around 1,527,668 people will be displaced aftermaths an earthquake (CDMP, 2009a, 2009b, 2009c).

An assessment was piloted by ADPC from February 2008 to August 2009 in Bangladesh Government initiatives titled on Comprehensive Disaster Management Program (CDMP). According to this study, a 7.5 magnitude earthquake originated from the Madhupur fault could have killed at least 1,30,000 people if the earthquake had been attacked in daytime in Dhaka. An earthquake of 8 Richter scale created close to the Chittagong of plate boundary fault 2 may kill about 69,900 people living in the capital if the earthquake had been attacked in daytime. There may 13,600 people need to be hospitalized and 61,288 people may need first aid treatment (CDMP, 2010). The planning interference in emergency evacuation preparedness (Chakrabarty, Rahman and Ubaura, 2020) may reduce the hazard impact (Rahman, Tariq and Sharmin, 2020). Thus, the capital city Dhaka and Bangladesh both are extremely vulnerable to earthquake and considering these aspects the earthquake vulnerability in the study area of Lalmatia was conducted. The Study was also conducted to realize the public's awareness about the willingness of building owners to retrofit the existing building against earthquake vulnerability.

\section{Objectives and Methods}

The main aim of this research is to assess the earthquake vulnerability of Lalmatia area, Dhaka city. To implement this aim, the following objectives have been taken into consideration: to assess the earthquake vulnerability in the existing buildings using Turkish Method and to investigate the earthquake vulnerability priority using Analytical Hierarchy Process.

Data for this research were collected through field observation and checklist survey. Primary data will be collected about number about stories, existence of a soft story, apparent building quality, existence of heavy overhangs, shape of the building, existence of short columns and pounding effect. For the study sample size is calculated through the following procedure: Total population (Building) size $(\mathrm{N})=1647$, Error level (e) $=5 \%$, Confidence level $95 \%$ and sample size was determined as 316. Secondary data were collected from different published and unpublished materials, journals, websites of different responsible organization etc.

\section{Study Area}

Lalmatia (Map 1) is located between Mohammadpur and Dhanmondi in the heart of Dhaka, Bangladesh. Geographically the area located at latitude $23^{\circ} 45^{\prime} 20.2068^{\prime \prime} \mathrm{N}$ and longitude $90^{\circ} 22^{\prime} 6.9276^{\prime \prime}$ E (Wikipedia, 2019). Known for its slender streets, and red bricked houses are now being currently experiencing a full-scale renovation. Satmasjid road, Old 27 number road and Mirpur road enclosures lalmatia from three sides. (Wikipedia, 2019) 


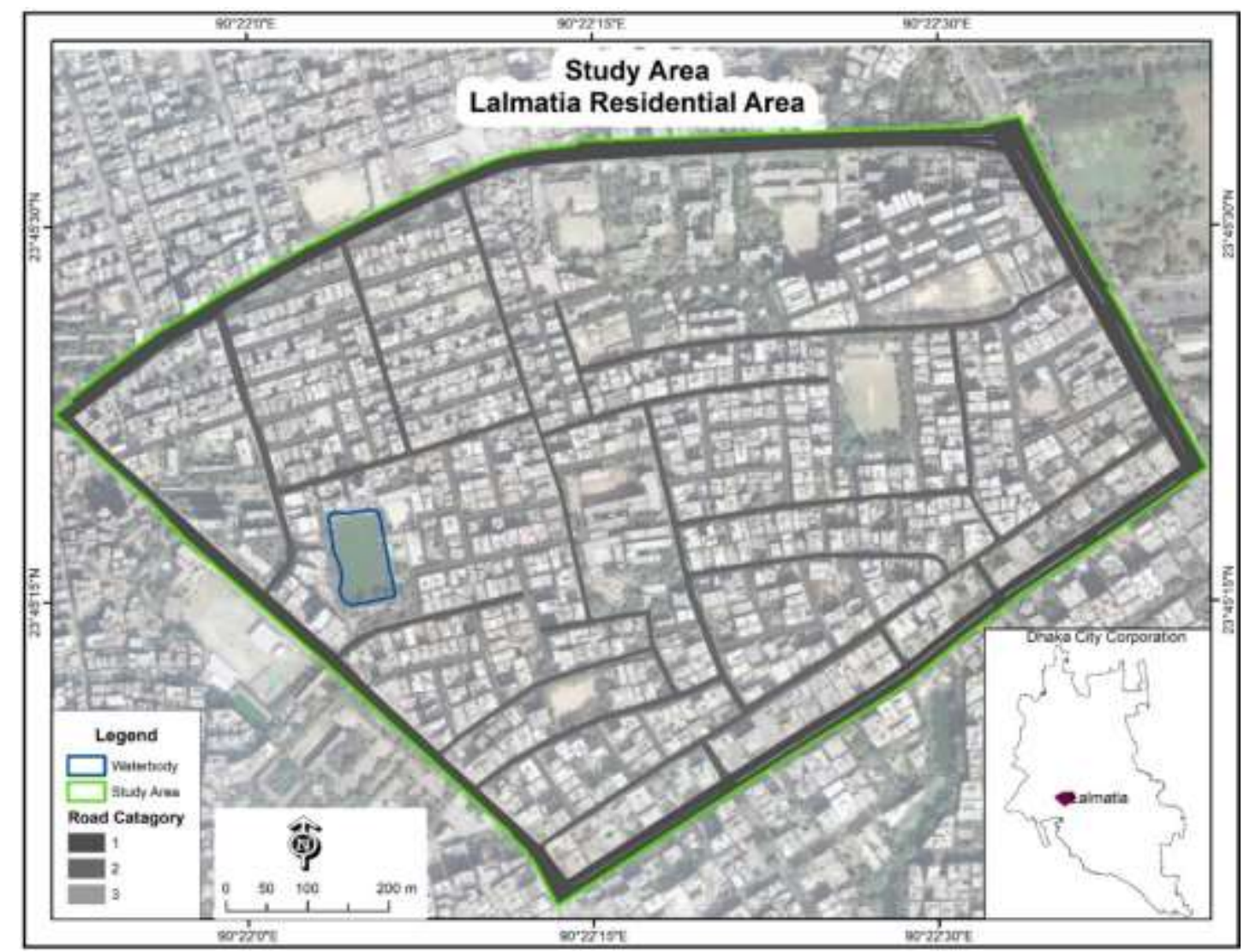

Source: Developed by author, 2019

Map 1: Study Area Map

\section{Turkish Method}

The Turkish government and the Japan International Cooperation Agency (JICA) came forward to implement a regional earthquake assessment and rehabilitation program after the 1999 earthquake in Kocaeli and Duzce. The Turkish method Level-1 is used in this work. The first phase of the survey from the sidewalk was conducted by observers through a walkdown visit.

\section{Survey Parameters}

The parameters selected in the Level-1 survey to indicate building vulnerabilities are as follows:

- General Information: Type of existing building, Number of building stories, Year of construction, Number of occupants, Maintenance record.

$>$ Appearance of a Soft Story:

$>$ Appearance of Heavy Overhangs:

$>$ Discernible Building Quality:

$>$ Pounding possibility Between Adjacent Buildings:

$>$ Appearance of a Short Columns:

$$
\begin{aligned}
& \text { Yes }(=1) \text { or No }(=0) \\
& \text { Yes }=1 \text { or No }=0 \\
& \text { Good }=0, \text { Moderate }=1 \text { or Poor }=2 \\
& \text { Yes }=0 \text { or No }=0 \\
& \text { Yes }=1 \text { or No }=0
\end{aligned}
$$

The intensity of ground motion at a particular location depends mainly on the efficiency of the distance and the local soil conditions. There is a strong relationship between PGV (Peak Ground Velocity) and local soil shear wave velocity (Chowdhury, 1993). So PGV was selected to represent the intensity of ground motion in the study. Peak ground velocity (PGV) can be taken between $40 \mathrm{~cm} / \mathrm{sec}$ to $50 \mathrm{~cm} / \mathrm{sec}$ (Wu et al., 2003). Thus, Zone II (40

\begin{tabular}{|c|c|c|}
\hline $\begin{array}{l}\text { Number of } \\
\text { Stories }\end{array}$ & \begin{tabular}{|ll} 
Base & Scores \\
$($ BS $)$ & \\
\end{tabular} & Vulnerability Scores (VS) \\
\hline
\end{tabular}
$<\mathrm{PGV}<60)$ is considered for calculating performance scores because our study area matched the same characteristics with Zone II. The different base scores described in Table 1 which were determined based on the number of stories and the earthquake risk level in the site building.

Table 1: Base Score (BS) and Vulnerability Score (VS) for Concrete Buildings 


\begin{tabular}{|l|l|l|l|l|l|l|}
\hline & Zone II & Soft Story & $\begin{array}{l}\text { Heavy } \\
\text { Overhang }\end{array}$ & $\begin{array}{l}\text { Apparent } \\
\text { Quality }\end{array}$ & $\begin{array}{l}\text { Short } \\
\text { Column }\end{array}$ & Pounding \\
\hline 1 or 2 & 130 & 0 & -5 & -5 & -5 & 0 \\
\hline 3 & 120 & -15 & -10 & -10 & -5 & -2 \\
\hline 4 & 100 & -20 & -10 & -10 & -5 & -3 \\
\hline 5 & 85 & -25 & -15 & -15 & -5 & -3 \\
\hline 6 or 7 & 80 & -30 & -15 & -15 & -5 & -3 \\
\hline
\end{tabular}

\section{Building Seismic Performance}

At first the vulnerability factors are fixed by the walk down survey and then the location of the building is determined by its location (by GPS survey), the seismic Performance Score (PS) can be finding out by using Eq. 1. The base score (BS), the Vulnerability Scores Multiplies (VSM) and the vulnerability scores (VS) to be used in Eq. 1 and the corresponding values are represented in tables 1

$\mathrm{PS}=(B S)-\sum(V S M) \times(V S)$

Then, the vulnerability value is found which is equal to the PS divided by BS. If this computed value is low, the vulnerability of the building will be high. Decide the range of vulnerability levels (Table 2) in the study (very low, low, medium, high and very high) and develop a map of vulnerability of concrete buildings.

Table 2: Vulnerability Score

\begin{tabular}{|l|l|}
\hline Score & Vulnerability Level \\
\hline $0.1-0.2$ & Very High \\
\hline $0.21-0.4$ & High \\
\hline $0.41-0.6$ & Moderate \\
\hline $0.61-0.8$ & Low \\
\hline $0.81-1$ & Very Low \\
\hline
\end{tabular}

Source: Sucuoglu and Yazgan, 2003

This assessment process of building vulnerability is only applicable for RCC (pucca) building. In this process tin shed and semi pucca buildings are not evaluate for the vulnerability assessment of the study area.

\section{Analytical Hierarchy Process (AHP):}

The AHP approve the decision maker to create a model consisting complex problem in hierarchical way indicating the relevance of the goal, criteria, sub criteria and alternatives. It additionally permits the decision maker to incorporate each subjective and objective concerns during this method (saaty, 1980). The AHP method involves the following basic steps:

$>$ Construction of the hierarchy

$>$ Comparative judgments or executing data collection to achieve pair wise comparison data of the hierarchical structure on elements.

$>$ Overall priority rating construction (Harker \& Vargas, 1987)

At the first stage, decision maker's necessity to break down the complex multiple criteria decisions into its component. At each level of hierarchy, the criteria and sub criteria are not equally important to taking decision. In the decision-making task, AHP is able to consolidate and combine the evaluations of the criteria and alternatives by group or individual (Eastman et al., 1993). AHP and Multi criterion analysis is using in this study to explore the vulnerability of Lalmatia against earthquake torment. Table 3 explore that six parameters were selected to vulnerability appraisement and then six factors are further categorized into five sub criteria. Factors affecting the vulnerability against earthquake is shown in table 3 .

Table 3: Factors Affecting Vulnerability along Their Weight

\begin{tabular}{|l|l|l|l|l|l|l|}
\hline \multirow{2}{*}{ Main Criteria } & \multirow{2}{*}{ Following Criteria } & \multicolumn{2}{|l|}{ Vulnerability } \\
\cline { 3 - 8 } & $\begin{array}{l}\text { Very } \\
\text { High }\end{array}$ & High & Medium & Low & $\begin{array}{l}\text { Very } \\
\text { Low }\end{array}$ \\
\hline & Wight & 9 & 7 & 5 & 3 & 2 \\
\hline
\end{tabular}




\begin{tabular}{|c|c|c|c|c|c|c|}
\hline \multirow{5}{*}{$\begin{array}{l}\text { Building } \\
\text { Vulnerability by } \\
\text { Turkish Method }\end{array}$} & $0.1-0.2$ & $\bullet$ & & & & \\
\hline & $0.21-0.40$ & & - & & & \\
\hline & $0.41-0.60$ & & & • & & \\
\hline & $0.61-0.80$ & & & & • & \\
\hline & $0.81-1$ & & & & & $\cdot$ \\
\hline \multirow{5}{*}{$\begin{array}{l}\text { Construction Year } \\
\text { of Building }\end{array}$} & Before 1970 & - & & & & \\
\hline & $1970-1980$ & & $\cdot$ & & & \\
\hline & 1981-1990 & & & • & & \\
\hline & $1991-2000$ & & & & $\cdot$ & \\
\hline & $2001-2010$ & & & & & • \\
\hline \multirow{5}{*}{$\begin{array}{l}\text { Population per } \\
\text { Building }\end{array}$} & 91 and more & $\bullet$ & & & & \\
\hline & $90-71$ & & $\cdot$ & & & \\
\hline & $70-40$ & & & - & & \\
\hline & $40-21$ & & & & • & \\
\hline & $20-0$ & & & & & $\cdot$ \\
\hline \multirow{5}{*}{ Area of Parcel } & Less than $100 \mathrm{~m}^{2}$ & - & & & & \\
\hline & $101-250 \mathrm{~m}^{2}$ & & $\cdot$ & & & \\
\hline & $251-500 \mathrm{~m}^{2}$ & & & • & & \\
\hline & $501-1000 \mathrm{~m}^{2}$ & & & & $\cdot$ & \\
\hline & More than $1000 \mathrm{~m}^{2}$ & & & & & • \\
\hline \multirow{4}{*}{ Road Width } & Less than $10^{\prime}$ & $\cdot$ & & & & \\
\hline & $10^{\prime}-20^{\prime}$ & & $\cdot$ & & & \\
\hline & $21^{\prime}-30^{\prime}$ & & & - & & \\
\hline & More than $30^{\prime}$ & & & & $\cdot$ & \\
\hline \multirow{5}{*}{ Building Use } & Residential & & • & & & \\
\hline & Educational & & & $\cdot$ & & \\
\hline & Commercial & & & & $\cdot$ & \\
\hline & Service Facilities & & & & & $\cdot$ \\
\hline & Official & & & & & • \\
\hline
\end{tabular}

\section{Pair-wise Comparison}

Saaty (1980) developed the pair wise comparison method in the context of AHP (Analytical Hierarchy Process). Comparisons create a ratio matrix, as it takes the parameter in pair wise to produce the relative weights. Personal and subjective judgements can be taken in comparison (Chen, 2016). At a given time, two elements compared of this analysis can reduces the conceptual complexity (Muralidhar et al., 1990; Parvoti, 1992; Saaty, 1980). Three task involves in this analysis:

$>$ A comparison matrix development at each level of hierarchy

$>$ Relative weights calculation for each element of hierarchy

$>$ Consistency ratio estimating to check the judgment consistency (Li et al., 2006)

Table: 4: Relative Important Scale of Point Intensity

\begin{tabular}{|l|l|l|}
\hline Importance Ranking & Meaning & Description \\
\hline $\mathbf{1}$ & Equal rank & Two events give equal judgment \\
\hline $\mathbf{3}$ & $\begin{array}{l}\text { Weak position of one over } \\
\text { another }\end{array}$ & $\begin{array}{l}\text { Results are marginally favor one action over } \\
\text { another }\end{array}$ \\
\hline $\mathbf{5}$ & Strong importance & Result strongly favor one activity over another \\
\hline $\mathbf{7}$ & Confirmed importance & $\begin{array}{l}\text { Strongly favored an activity and its control is } \\
\text { validated in practice }\end{array}$ \\
\hline $\mathbf{9}$ & Entire importance & $\begin{array}{l}\text { Strongly favored an activity and is the } \\
\text { maximum potential order of confirmation }\end{array}$ \\
\hline $\mathbf{2 , 4 , 6 , 8}$ & Middle values between the two- & Negotiation is required \\
\hline
\end{tabular}




\begin{tabular}{|l|l|l|}
\hline $\begin{array}{l}\text { Reciprocals of Above } \\
\text { Nonzero }\end{array}$ & $\begin{array}{l}\text { neighboring decision } \mathrm{i} \text { shows the above nonzero numbers in the activity when comparing to activity } \mathrm{j}, \\
\text { then } \mathrm{j} \text { will be common values in relating with } \mathrm{i}\end{array}$ \\
\hline
\end{tabular}

Source: Saaty, (1980)

Analytical hierarchy used the 9-point Scale for ranging from $\mathbf{1}$ to $\mathbf{9}$ (indifference or equal importance to extreme preference or absolute importance) which is shown in table 4. In this comparison matrix elements are compared in pairs in each level with respect to importance. The decision maker evaluates the contribution of each factor in this pair wise comparison matrix. In the comparison matrix at a given level will be reduced to a number of square matrices $M=\left[a_{i j}\right]_{n \times n}$ as in the following:

$$
\left[\begin{array}{cccc}
a_{11} & a_{12} & \cdots & a_{1 n} \\
a_{21} & a_{22} & \cdots & a_{2 n} \\
\cdots & \cdots & \cdots & \cdots \\
a_{n 1} & a_{n 2} & \cdots & a_{n n}
\end{array}\right]
$$

Vector of weights, $\left[\mathrm{W}=\mathrm{W}_{1}, \mathrm{~W}_{2}, \ldots \ldots \mathrm{W}_{\mathrm{n}}\right]$ is calculated after formed the pair wise comparison matrix. The matrix $\mathrm{M}=\left[\mathrm{a}_{\mathrm{ij}}\right]_{\mathrm{n} \times \mathrm{n}}$ is normalized by Equation 2 .

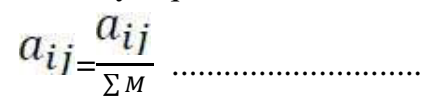

For all $\mathrm{j}=1,2, \ldots \mathrm{n}$.

To calculate the CR, the CI (Consistency Index) and RI (Random Index) for each level of matrix of order " $n$ " can be obtained from Equation 3 and Equation 4.

$$
\begin{aligned}
\mathrm{CI} & =\frac{\lambda_{\max }-n}{n-1} \quad \ldots \ldots \ldots \ldots \ldots . . . \\
\mathrm{RI} & =\frac{1.98(n-2)}{n} \quad \ldots \ldots \ldots \ldots \ldots . . .
\end{aligned}
$$

Then CR is computed using Equation 5.

$$
\mathrm{CR}=\frac{\mathrm{CI}}{\mathrm{RI}}
$$

Here, RI is Random Consistency Index shown in table 5 which is obtained from randomly generated pair wise comparison matric. The comparisons are acceptable if $\mathrm{CR}<0.1$ and the comparisons are not acceptable if $\mathrm{CR}>0.1$ which is inconsistent judgements. One should revise and reconsider in such cases with their original values in this matrix A

Table 5: Random Index

\begin{tabular}{|l|c|c|c|c|c|c|c|c|c|c|c|c|c|}
\hline N(number) & 2 & 3 & 4 & 5 & 6 & 7 & 8 & 9 & 10 & 11 & 12 & 13 & 14 \\
\hline $\begin{array}{l}\text { Random } \\
\text { Index (RI) }\end{array}$ & 0 & 0.58 & 0.9 & 1.12 & 1.24 & 1.32 & 1.41 & 1.45 & 1.49 & 1.51 & 1.48 & 1.56 & 1.57 \\
\hline
\end{tabular}

Source: Saaty, (1980)

\section{Discussions}

From the filed investigation (2019), it has been identified that several kind of land uses are presents in lalmatia like residential, commercial, educational, institutional, recreational etc. (Map 2). A very general picture in the study area are the first floor of buildings used for commercial purposes when the upper floors are completely residential. It was found that many mixed use activity like shops, service activity, residence are belonging the same building at a time. Lalmatia is now taken by developer and rapid development contributes to land use change in this area. Privatization is main factors of land use change. Residential land use increases day by day. Now the residential land use is $81.83 \%$ of the total land of Lalmatia area. Field survey reveals that Lalmatia is residential area, here most of the buildings use is residential. Second most use type is commercial, and then community service. Table 6 will present the number of building with their use.

Table 6: Number of building with their use.

\begin{tabular}{|c|c|}
\hline Building Use & Building Number \\
\hline Residential & 1347
\end{tabular}


Commercial

Educational and Research

Mixed use

Community Service

Government Services

Total

Source: Field survey, 2019

In case of response and recovery phase after a severe earthquake, road network especially road width has great momentous in moving the emergency vehicles. The road network of Lalmatia area is far better now. The road network has a deep relation with urban development because the easy communication system attracts all types of development. Development of road network contributes to urbanization in this area. Road map in Lalmatia area is shown on map 3.

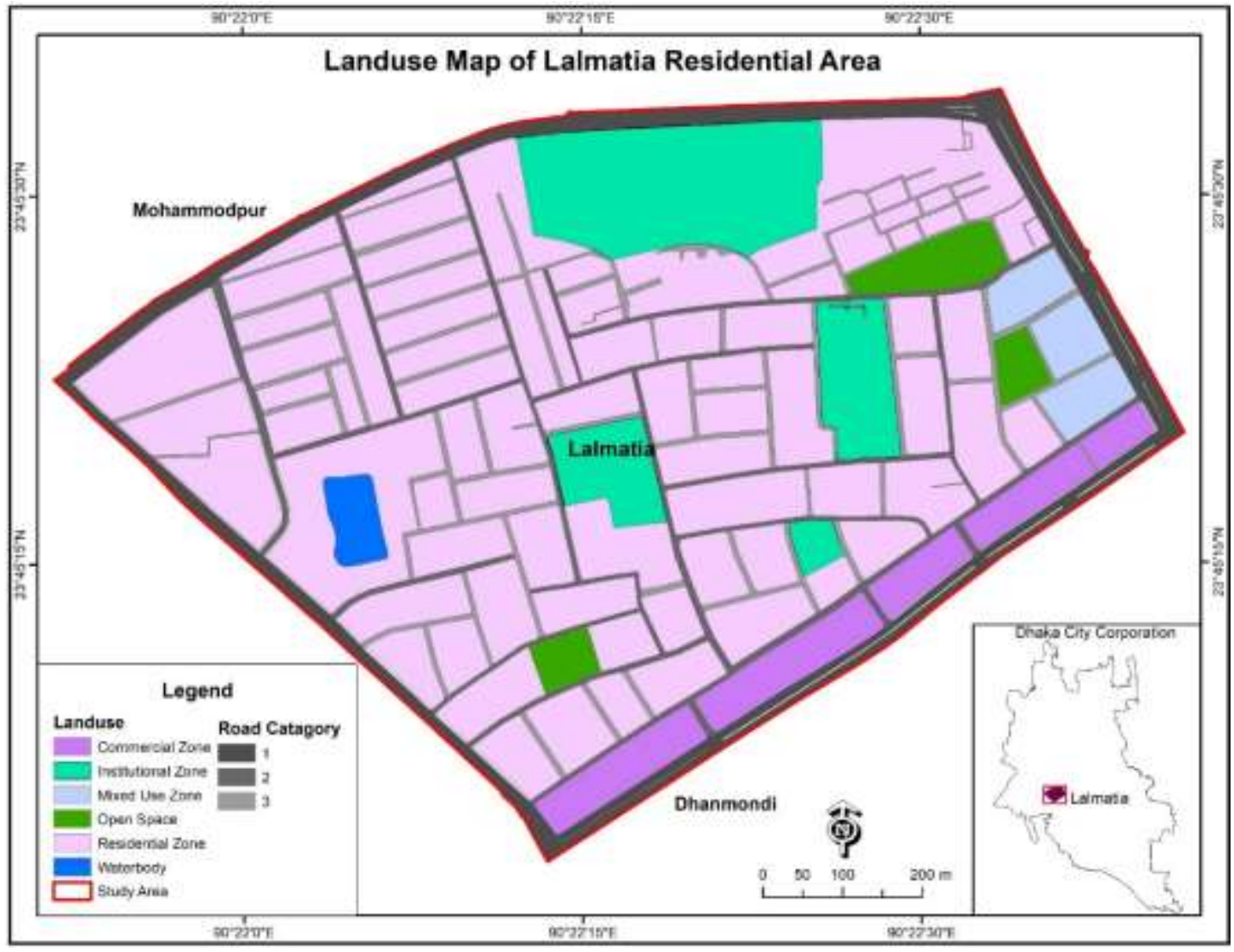

Source: Developed by Author, 2019

Map 2: Land use Map of Study Area 


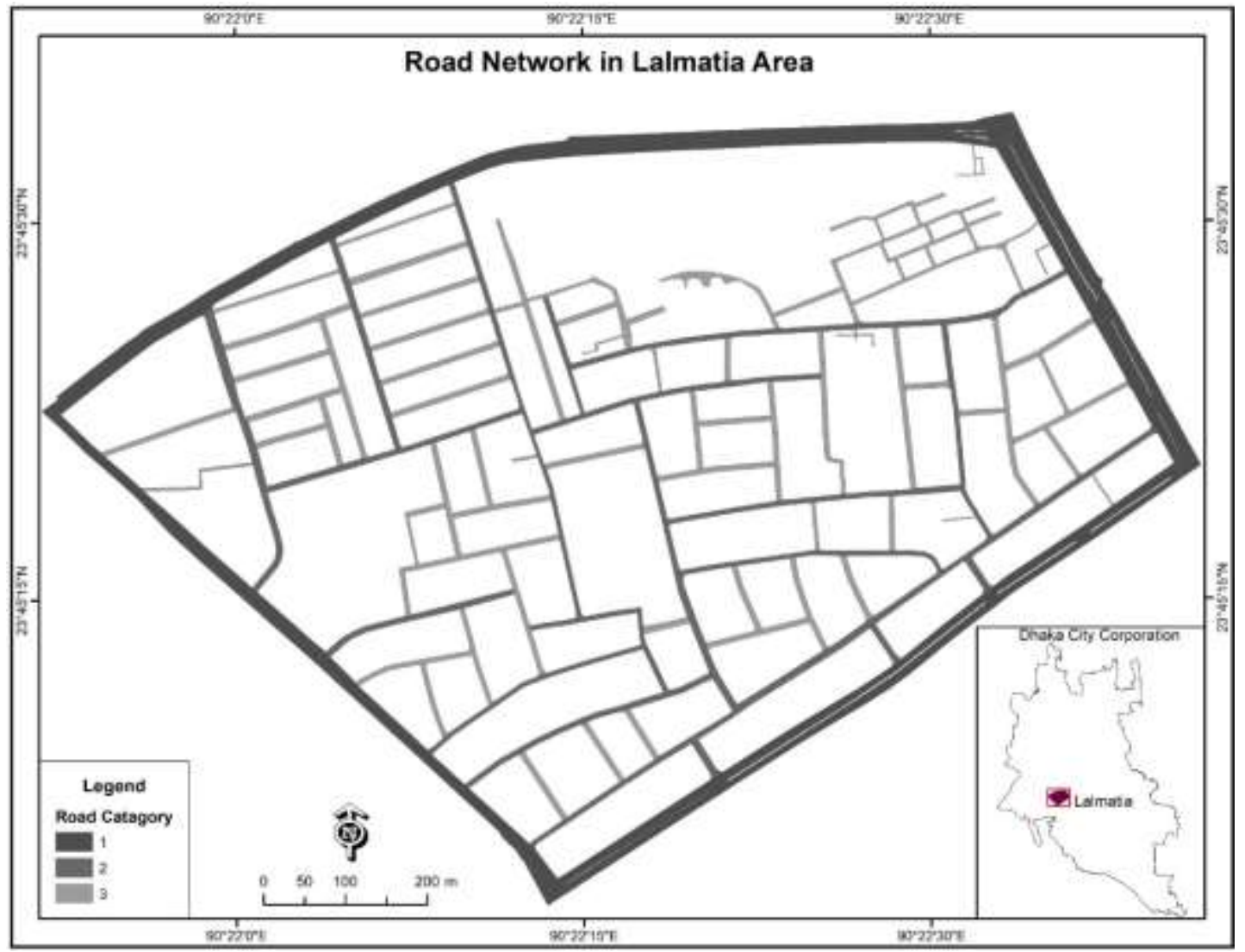

Source: Developed by Author, 2019

Map 3: Road Network Map of Lalmatia Area

There are different types of a buildings structure in Lalmatia area. Both contain three types of building like RCC, masonry and semi-pucca building (Map 4), but they are different in amount. Most of the building types are RCC. The modern RCC buidings are comparatively more safer during earthquake than old-fashion masonry building. The masonry structures are more risky during earthquake or building collapse. 


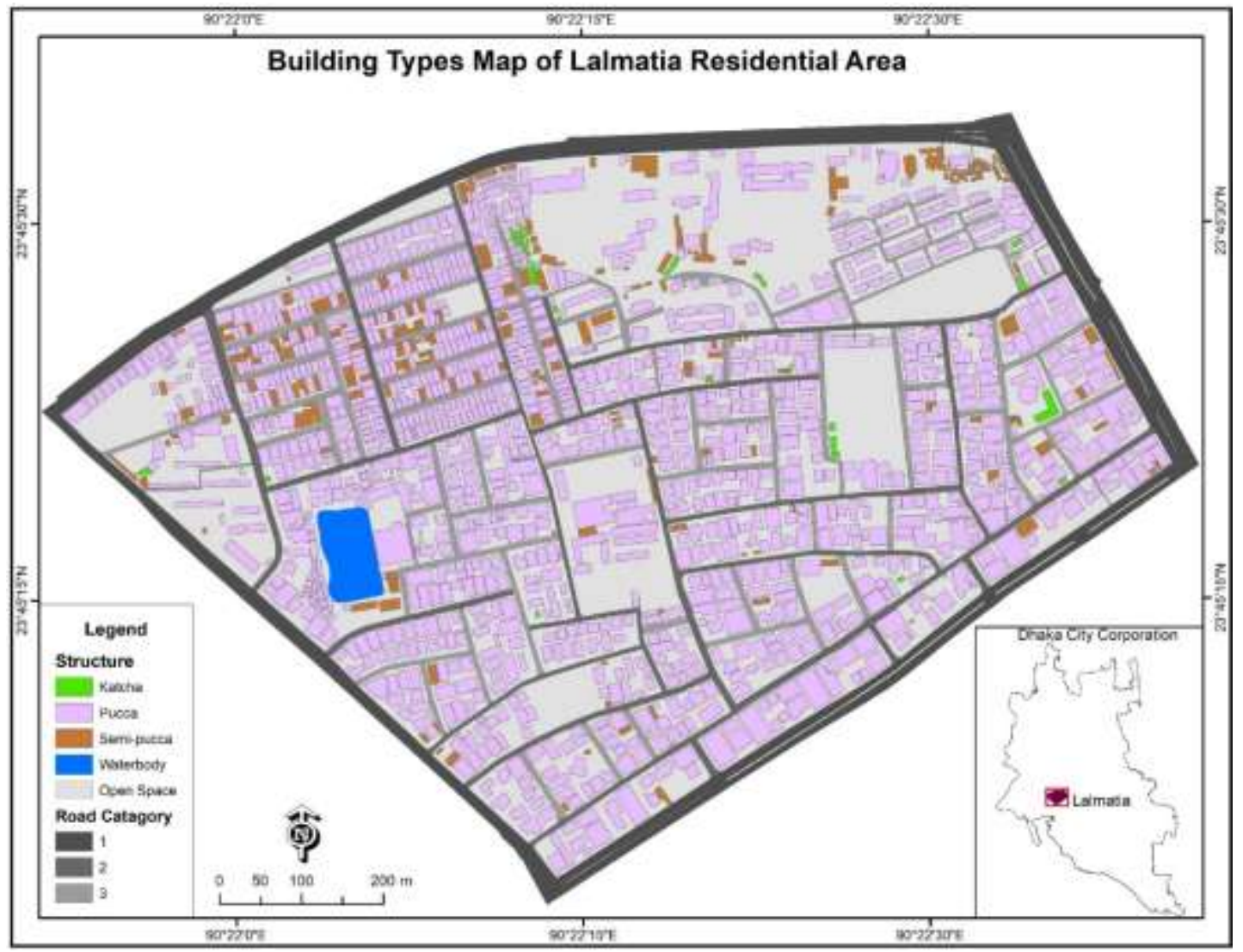

Source: Developed by author, 2019

Map 4: Building Types Map of Study Area

Nowadays the structural development occurred and high-rise buildings are constructed rapidly. In Lalmatia area, 6 storied, 10 storied and 14 storied buildings are available. Different developer and private real estate firm constructed many high-rise buildings in this area. Different private hospitals, organization offices, commercial buildings, etc. are constructed at this time period. Arrangement of the buildings in the study area according to build height is shown on map 5 .

The relation between numbers of buildings with the presence of short columns (Existence/ Nonexistence) in the building are displayed in the table 7 . Table 7 shows that about $4 \%$ buildings have short columns. Due to the Presence of the short columns, building makes it subject to Torsional effect.

Table 7: Presence of Short Columns

\begin{tabular}{|l|l|l|l|}
\hline Presence of short Column & Existent & Non-Existent & Total \\
\hline Criteria & 13 & 303 & 316 \\
\hline No. of Building & $4 \%$ & $96.00 \%$ & $100 \%$ \\
\hline \% of Presence of Short Column & \multicolumn{3}{|c|}{ Source: Field Survey, 2019} \\
\hline
\end{tabular}




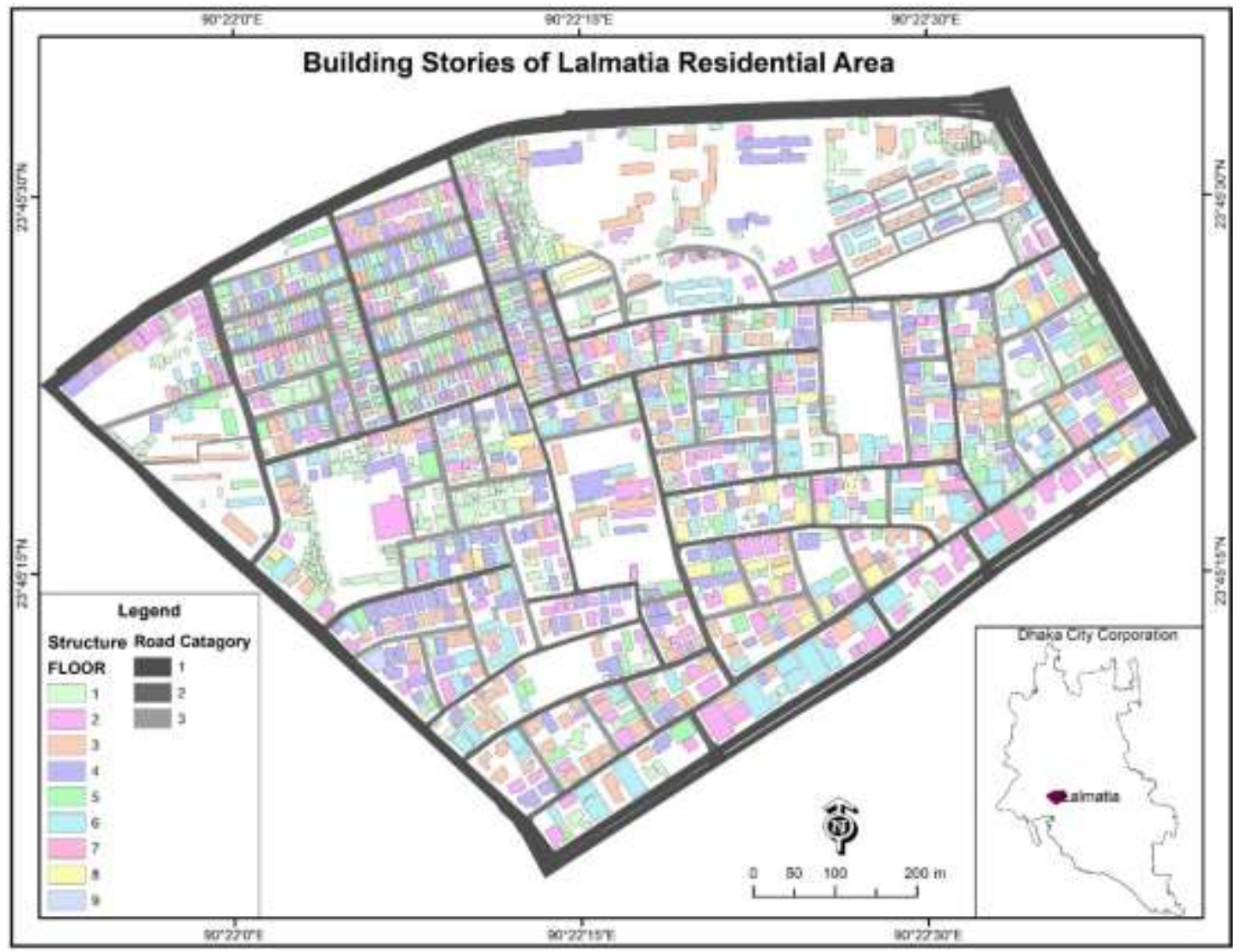

Source: Developed by author, 2019

Map 5: Building Stories Map of Study Area

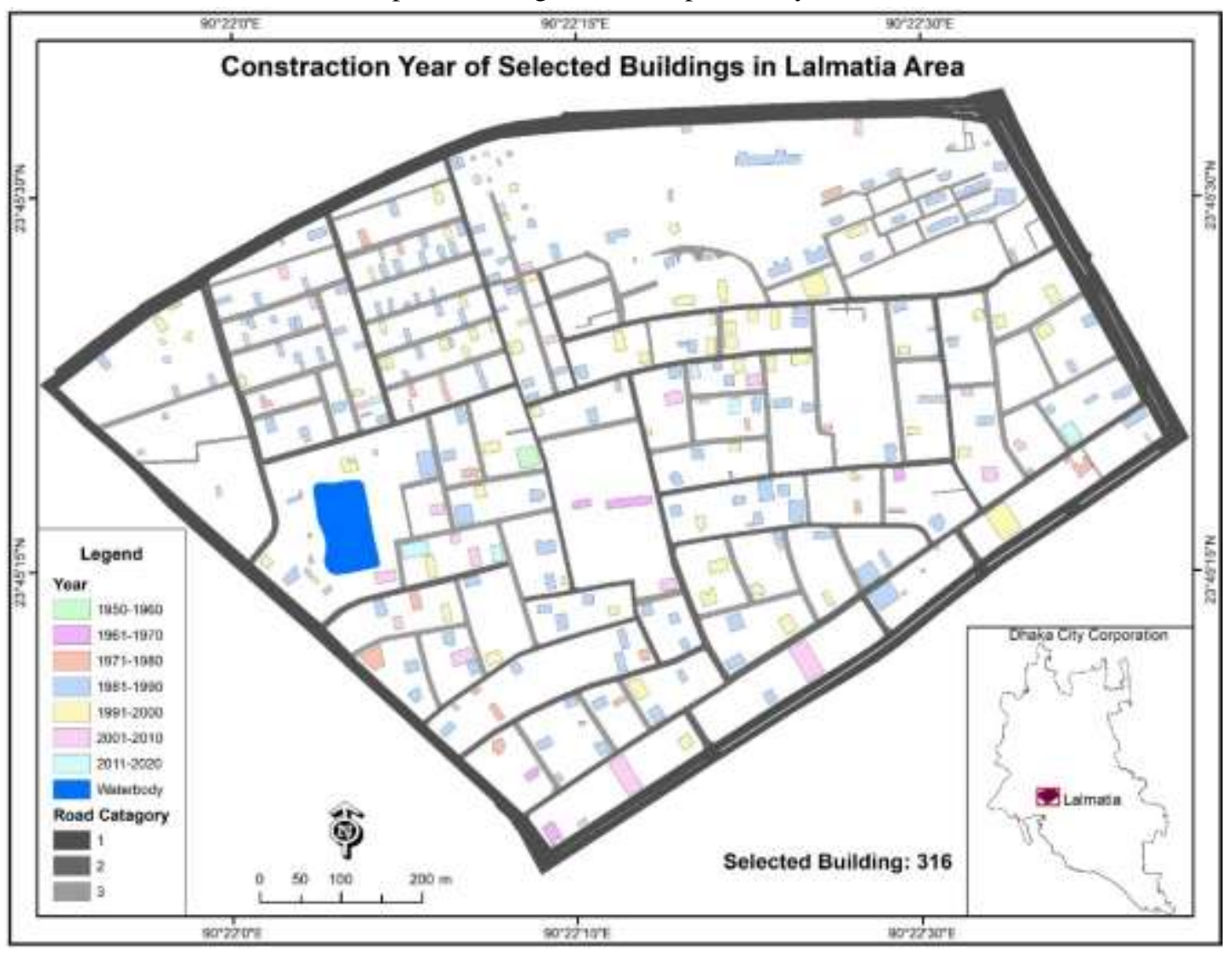

Source: Developed by author, 2019

Map 6: Construction Year Map of Selected Buildings 
For analyzing the current building vulnerability of the study area, 316 buildings (map 7) were selected based on preliminary survey. Such buildings were selected which are RCC, masonry and others type of buildings having one to above ten stories. The survey for seismic vulnerability analysis was mainly focused on earthquake issues such as identifying building type, number of building story, presence of soft story, presence of heavy overhang, apparent building quality, presence of short column, pounding effect, number of inhabitants, area of parcel, road width, building use, year of construction, etc.

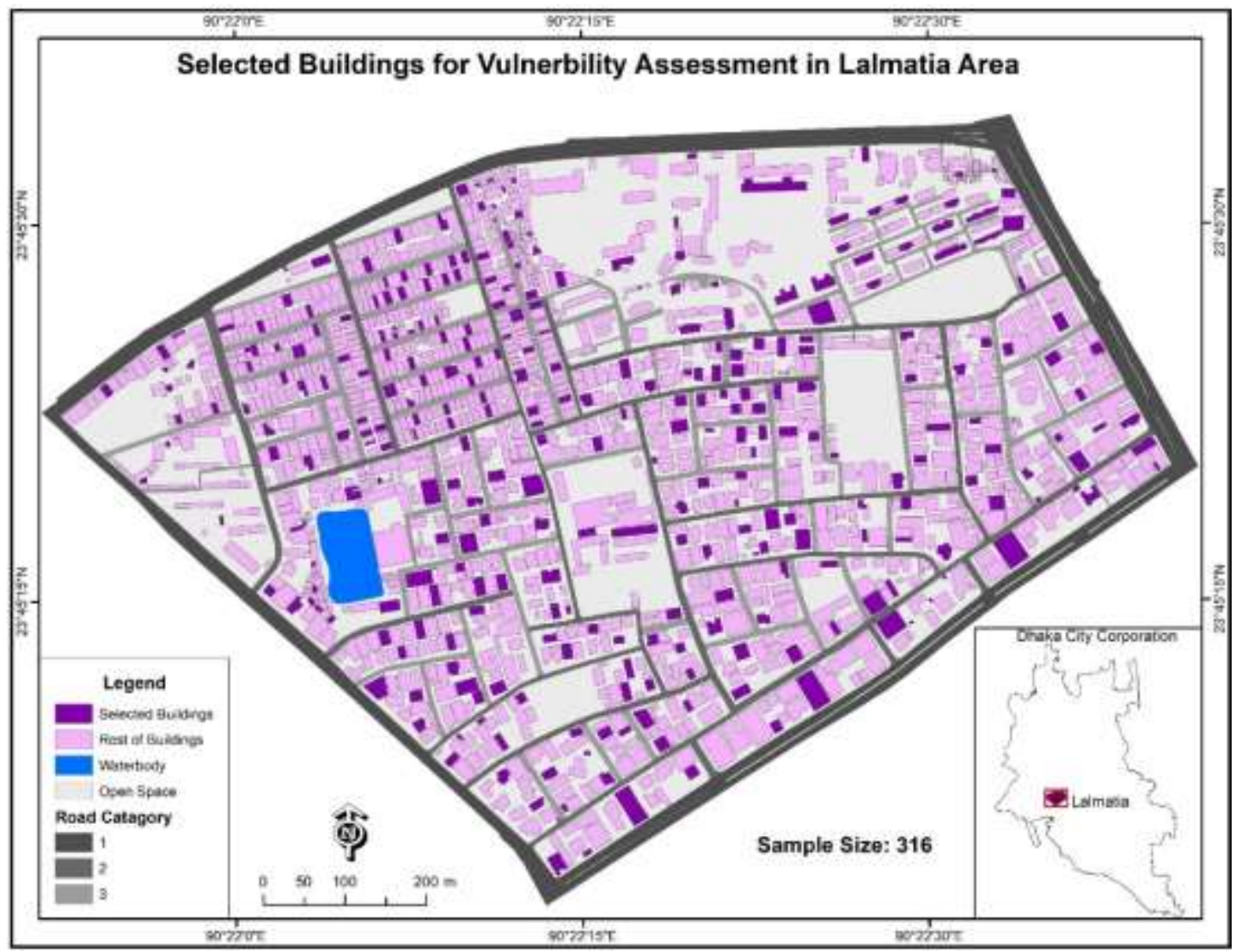

Source: Developed by Author, 2019

Map 7: Selected Building for vulnerability Assessment

Lalmatia contain three types of building like RCC, masonry and semi-pucca building, but they are different in amount. Most of the building types are RCC. The relation between numbers of buildings with the number of stories (such as one-two, three-four, five-six and above stories) are shown in figure 1. Figure shows that, five to six stories buildings are more (31.3\%) than other stories in the study area (Figure 1). After 2005, construction and reconstruction of buildings is increasing most in Lalmatia. Among 2005-2014, almost 47.8\% buildings are constructed. Before 2005 building construction was more in 1985 to 1995 . Again, construction of structures is increasing in last ten years (Figure 2).

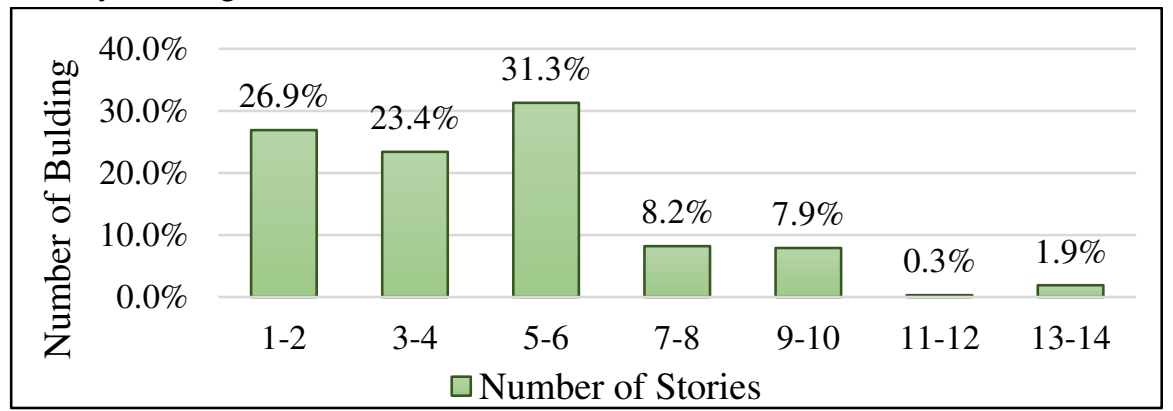

Source: Field survey, 2019

Figure 1: Number of Stories of Building 
In figure 3 represent the relation between numbers of buildings with the presence of heavy overhangs. In the study area, found that most buildings tend to have overhangs (mostly balcony). Here, almost 38\% building having a heavy overhang. Buildings with heavy overhang was built in most of the upper floor from two to three feet. Figure 4 reveals that the percentage of soft story buildings are less than the buildings without soft story. Almost $38 \%$ buildings having soft story. Figure 5 shows the relation between numbers of buildings with the apparent building quality in the study area. It is found that the majority of the apparent building quality is good in Lalmatia area, and it is almost $59.2 \%$.

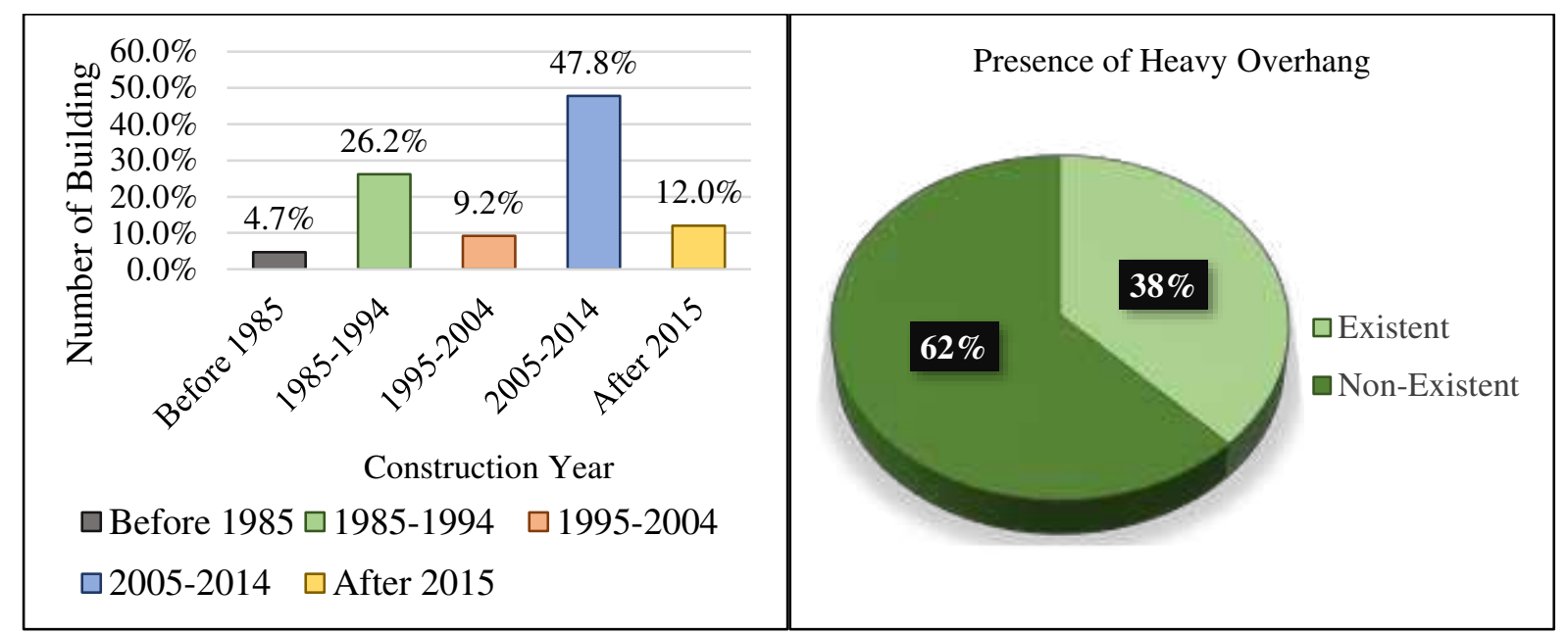

Figure 2: Construction Year of Building

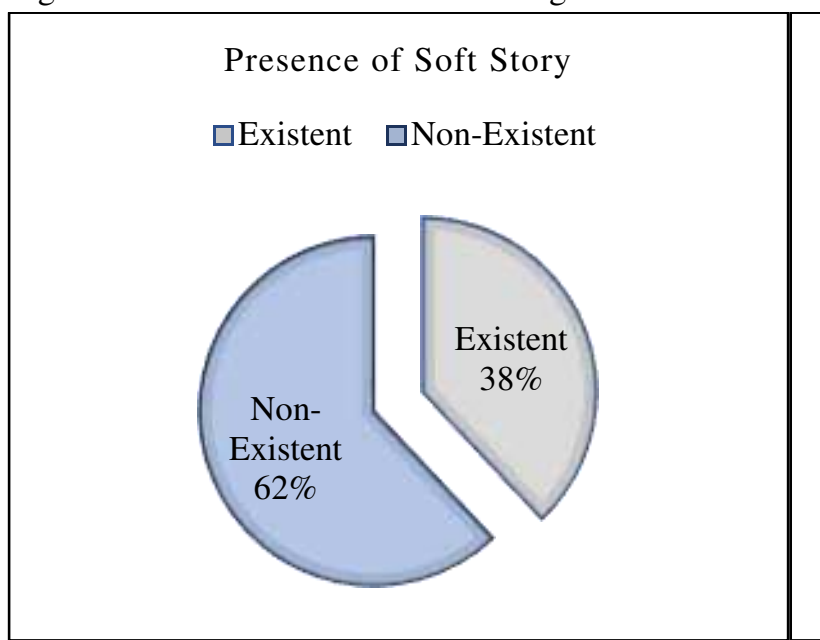

Figure 4: Presence of Soft Story
Figure 3: Presence of Heavy Overhang

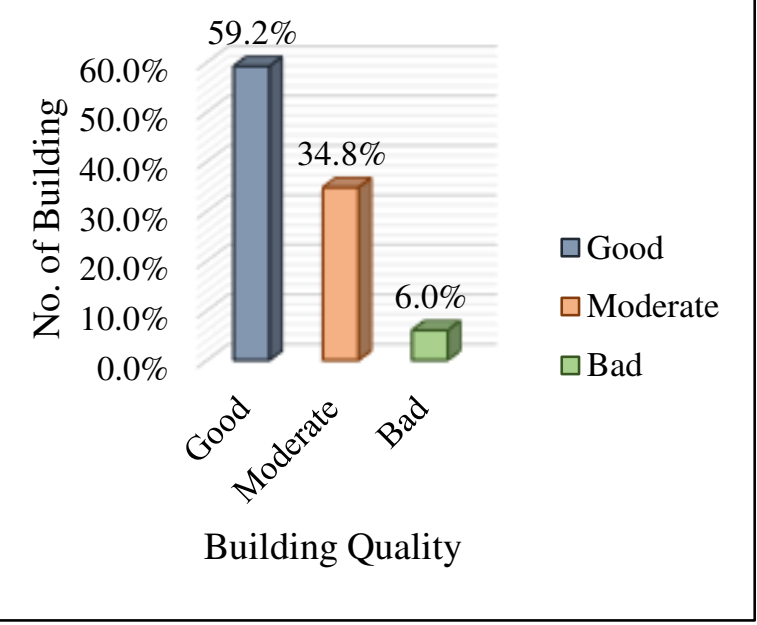

Figure 5: Apparent Building Quality

Source: Field survey, 2019

Figure 6 represents the relationship between numbers of buildings with adjacent buildings pounding possibility. It is found from field survey that the majority of the buildings have been pounding possibility. Almost 59.8\% buildings having pounding possibility. Lalmatia is the residential area and figure 7 depicts that almost $83.2 \%$ of the buildings used as residential purpose. Others building used for the purpose of commercial, service activity, education, and mixed purpose. 


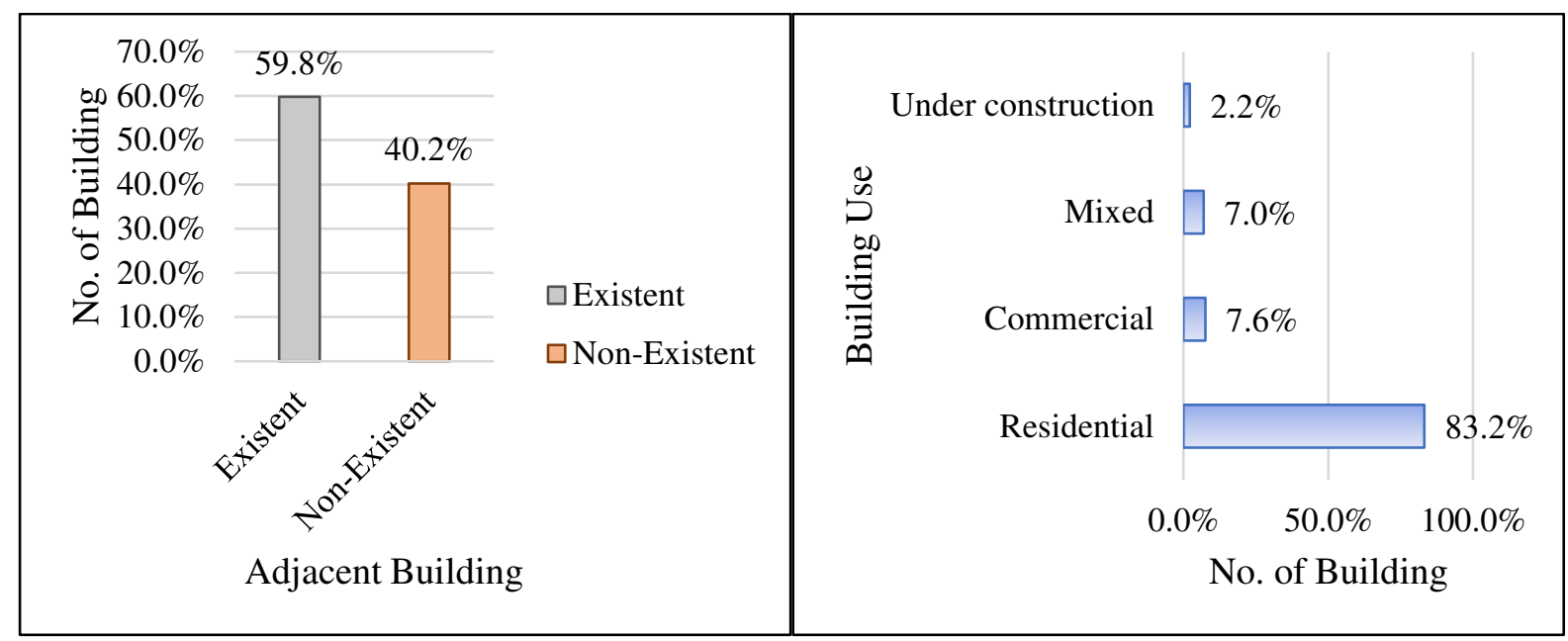

Figure 6: Pounding between Adjacent Building

Figure 7: Percentage of Building Use

Source: Field survey, 2019

\section{Vulnerability Scoring by Turkish Method}

This vulnerability scoring conducted on the total 316 building. To develop vulnerability score of these buildings first assigns the value of the given (table 1) parameter for individual building. Calculate a performance score (PC) of an individual building by using the base score from table 1 . Then find PS using, PS $=(\mathrm{BS})-\sum(\mathrm{VSM}) \times(\mathrm{VS})$.

\section{Example}

\begin{tabular}{|c|c|c|c|c|}
\hline \multirow{2}{*}{$\begin{array}{l}\text { Base Zone } 2 \\
\text { No. of Storied-3 }\end{array}$} & & & \multicolumn{2}{|c|}{ Basic Score $=120$} \\
\hline & VSM & & VS & $\mathrm{VSM} \times \mathrm{VS}$ \\
\hline Soft Story & Yes & 1 & -15 & -15 \\
\hline Heavy Overhang & No & 0 & 0 & 0 \\
\hline Apparent Quality & Moderate & 1 & -10 & -10 \\
\hline Short Column & Yes & 1 & -5 & -5 \\
\hline Pounding Possibility & No & 0 & 0 & 0 \\
\hline$\sum(\mathbf{V S M}) \times(\mathrm{VS})$ & & & & -30 \\
\hline
\end{tabular}

Source: Developed by author, 2019

For calculating the vulnerability value individual PS divided by BS.

Performance Score $(\mathrm{PS})=$ Base Score $-\sum(\mathrm{VSM}) \times(\mathrm{VS})$

So, Vulnerability Value $=$ PS/BS

$$
=120-30=90
$$

$$
=90 / 120=0.75
$$

If the vulnerability value is low, the vulnerability of the building is high. Define a range of vulnerability levels (very high, high, moderate, low and very low) and developing the vulnerability map (Map 8) of the RCC building of Lalmatia.

\section{Overall Vulnerability Scoring by AHP}

AHP (Analytical Hierarchy Process) is a flexible, effective, and simple method to decision-making process. Saaty proposed the AHP method in 1980. It is a familiar method that decomposes several level decision-making problems through creating hierarchical relationship between different levels. This method uses comparison as a pair to distribute weights of different factors that helps to measuring the relative importance through the suing Saaty's 1 to 9 level scales. Consistency ratio (CR) is also calculating to verify the judgmental coherence. The accepted consistency ratio must be about 0.1 or less. This method includes following three steps-

$>$ Two comparison matrices generation

$>$ Calculation of weights for different factors

$>$ Calculation of agreement ratio 


\section{Generating of a Binary Comparison Matrix}

According to Saaty, a pair wise comparison matrix is a numerical relationship between two elements that appreciate more important element. In the numerical representation the weight of each factor compared together. Matric $n \times n$ (in this case $6 \times 6$ ) record the results that also called binary comparison matric Aij $=[a n \times n]$. In Analytical Hierarchy Process, all elements of the metric are positive and concerning the "reverse condition" (the weight of $\mathrm{j}$ in regard to $\mathrm{i}$ will equal to $1 / \mathrm{k}$, if the weight of $\mathrm{i}$ in regard to $\mathrm{j}$ equals to $\mathrm{k}$ ). In every binary comparison matric, we will have two numerical quantity of Aij and 1/Aij.

\section{Calculation Step for Different Factors}

A comparison matrix (table 8) has been developed to ascertain the each factors weight. Calculation step includes the following:

Step 1: Computation of Weighted Sum Vector (WSV) table 8.

Table 8: Pair-wise Comparison Matrix of Six Vulnerability Factors

\begin{tabular}{|l|l|l|l|l|l|l|}
\hline Pair-wise comparison matrix (A1) & BV & CY & Pop $^{\text {n }}$ & AoP & RW & LU \\
\hline Criteria & 1 & 7 & 7 & 7 & 7 & 7 \\
\hline $\begin{array}{l}\text { Building Vulnerability by } \\
\text { Turkish Method (BV) }\end{array}$ & 0.143 & 1 & 2 & 4 & 6 & 7 \\
\hline $\begin{array}{l}\text { Construction Year of Building } \\
\text { (CY) }\end{array}$ & 0.143 & 0.5 & 1 & 2 & 4 & 5 \\
\hline Population per Building (Pop $)$ & 0.143 & 0.25 & 0.5 & 1 & 2 & 3 \\
\hline Area of Parcel (AoP) & 0.143 & 0.167 & 0.25 & 0.5 & 1 & 2 \\
\hline Road Width (RW) & 0.143 & 0.143 & 0.2 & 0.333 & 0.5 & 1 \\
\hline Land Use (LU) & $\mathbf{1 . 7 1 4 7 1}$ & $\mathbf{9 . 0 6}$ & $\mathbf{1 0 . 9 5}$ & $\mathbf{1 4 . 8 3 3}$ & $\mathbf{2 0 . 5}$ & $\mathbf{2 5}$ \\
\hline Sum & & \multicolumn{2}{|l}{ Source: Developed by author, 2019} \\
\hline
\end{tabular}

Step 2: Calculating the Inconsistency Vector (IV) (table 9).

Step 3: Attaining $\lambda_{\max }$ (table 9).

Table 9: Criteria Weight Calculation

\begin{tabular}{|c|c|c|c|c|c|c|c|c|c|}
\hline \multicolumn{7}{|c|}{ Normalized Pair-wise comparison matrix } & \multirow{2}{*}{$\begin{array}{l}\text { A2 } \\
\text { Criteria } \\
\text { Weight }\end{array}$} & \multirow{2}{*}{$\begin{array}{l}\mathbf{A} 3= \\
\sum \mathbf{A} 1 \times \mathbf{A} 2\end{array}$} & \multirow[b]{2}{*}{$\mathbf{A} 3 \div \mathbf{A} 2$} \\
\hline Criteria & BV & $\mathrm{CY}$ & Pop $^{n}$ & AoP & RW & $\mathrm{LU}$ & & & \\
\hline $\mathrm{BV}$ & 0.583 & 0.773 & 0.639 & 0.472 & 0.342 & 0.28 & 0.515 & 3.912 & 7.599 \\
\hline $\mathrm{CY}$ & 0.083 & 0.110 & 0.183 & 0.270 & 0.293 & 0.28 & 0.203 & 1.350 & 6.645 \\
\hline Pop $^{n}$ & 0.083 & 0.055 & 0.091 & 0.135 & 0.195 & 0.20 & 0.127 & 0.810 & 6.401 \\
\hline AoP & 0.083 & 0.028 & 0.046 & 0.067 & 0.098 & 0.12 & 0.074 & 0.459 & 6.238 \\
\hline RW & 0.083 & 0.018 & 0.023 & 0.034 & 0.049 & 0.08 & 0.048 & 0.292 & 6.100 \\
\hline LU & 0.083 & 0.016 & 0.018 & 0.022 & 0.024 & 0.04 & 0.034 & 0.210 & 6.181 \\
\hline \multicolumn{9}{|l|}{ Average } & 6.527 \\
\hline
\end{tabular}

Step 4: Calculation of Inconsistency Index: identified by equation (6).

$C I=\frac{\lambda_{\max }-n}{n-1}=\frac{0.527}{5}=0.105$

Step 5: Calculating the Inconsistency Ratio (CR):

Step 5: Calculation of Inconsistency Ratio (CR): defined by equation (7).

$C R=\frac{C I}{R I}=\frac{0.105}{1.24}=0.085$

Here,

$\mathrm{CI}=$ Consistency Index,

$\mathrm{RI}=$ Random Consistency Index,

$\mathrm{n}=$ Number of attributes,

and $\lambda_{\max }=$ Weighted Matrix

$\mathrm{RI}$ is derived from the table 5 . 
In our result the $\mathrm{CR}$ is estimated 0.085 which means there is a consent in result because we know that if CR is greater than 0.1 then the result should be reassessed and if $\mathrm{CR} \leq 0.1$ then it should be agreement in the result.

\section{Overall Vulnerability Evaluation}

The weights for the criteria are computed to evaluate the overall vulnerability using AHP method and afterwards vulnerability map of Lalmatia is prepared based on vulnerability level.

\section{Findings}

At the stage of Turkish Method, the range of vulnerability levels is depended on high rise, large, heavy overhang, huge soft story, have close change of pounding effect, short column existence is severe and apparent building quality is bad. Table 10 represents high vulnerable buildings score by Turkish method.

\section{Example}

Table 10: Vulnerability Score of Very High Vulnerable Building by Turkish Method

\begin{tabular}{|c|c|c|c|c|c|c|c|c|c|}
\hline 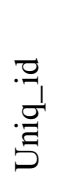 & 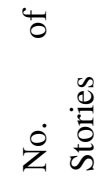 & 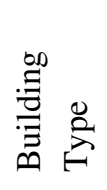 & $\begin{array}{l}\grave{0} \\
\stackrel{0}{\infty} \\
\stackrel{5}{0} \\
\ddot{n}\end{array}$ & 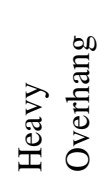 & 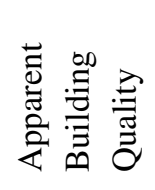 & 产 $\frac{\Xi}{\Xi}$ & 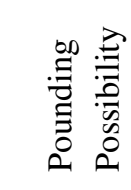 & $\stackrel{\infty}{:} \stackrel{0}{:}$ & 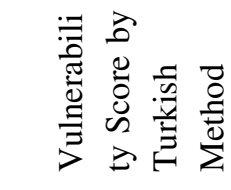 \\
\hline 761 & 6 & 1 & 1 & 1 & 2 & 2 & 1 & 1 & 0.19 \\
\hline 1571 & 6 & 1 & 1 & 1 & 2 & 2 & 1 & 1 & 0.20 \\
\hline 1406 & 10 & 1 & 1 & 1 & 2 & 2 & 1 & 1 & 0.20 \\
\hline 1532 & 6 & 1 & 1 & 1 & 2 & 2 & 1 & 1 & 0.19 \\
\hline 970 & 5 & 1 & 1 & 1 & 3 & 2 & 2 & 3 & 0.18 \\
\hline
\end{tabular}

Using Turkish method (total buildings 316) 21 buildings are high vulnerable, 5 buildings are very high vulnerable, 45 buildings are moderate vulnerable, 157 buildings are very low vulnerable, 88 buildings are low vulnerable found in the study area. Result of building vulnerability assessment (very high, high, moderate, low, and very low) by Turkish Method of the study area is shown map 8. 


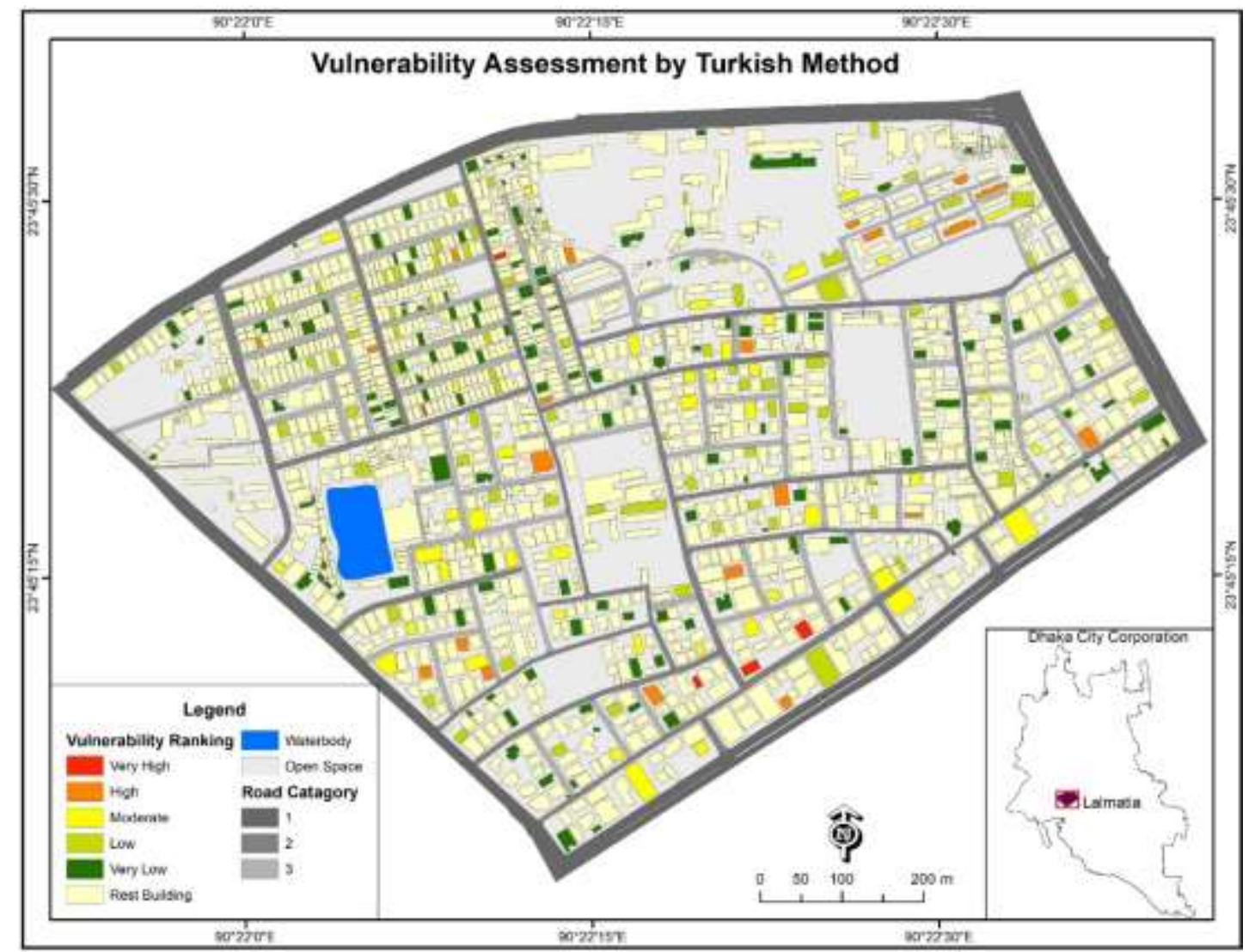

Source: Developed by author, 2019

Map 8: Vulnerability Assessment Map by Turkish Method

With the value of Turkish Method, at the time of AHP model the range of vulnerability levels is depended on huge population, very high construction age, narrow road and building use is residential. AHP considers all multiple aspects that can affect any building vulnerability and weighted with seismic buildings related factors and present the vulnerability category.

\section{Example}

Table 11: Vulnerability Score of Very High Vulnerable Building by AHP Method

\begin{tabular}{|l|l|l|l|l|l|l|l|l|}
\hline Uniq_id & $\begin{array}{l}\text { No of } \\
\text { stories }\end{array}$ & $\begin{array}{l}\text { Vulnerability Score by Turkish } \\
\text { Method }\end{array}$ & CY & Pop $^{\text {n }}$ & AoP & RW & LU & Score \\
\hline 761 & 6 & 0.19 & 1990 & 55 & 46.87 & 22 & R & 42 \\
\hline 1571 & 6 & 0.20 & 1998 & 52 & 322.13 & 22 & R & 36 \\
\hline 1406 & 10 & 0.20 & 1990 & 76 & 118.97 & 22 & R & 42 \\
\hline 1532 & 6 & 0.19 & 1990 & 54 & 283.68 & 26 & R & 40 \\
\hline 970 & 5 & 0.18 & 1990 & 37 & 106.43 & 22 & R & 38 \\
\hline
\end{tabular}

Source: Developed by author, 2019

According to AHP method, by giving a priority on very high vulnerable and high vulnerable building (Turkish method) represents the three priority ranking. In case of very high vulnerable buildings (total buildings 5), 2 buildings get first priority, 1 get second priority and 2 gets third priority. In case of high vulnerable building (total buildings 21), 13 buildings get first priority, 5 gets second and 3 gets third priority. This priority list represents priority-based retrofitting. Figure 8 represents the priority list of high vulnerable buildings. 

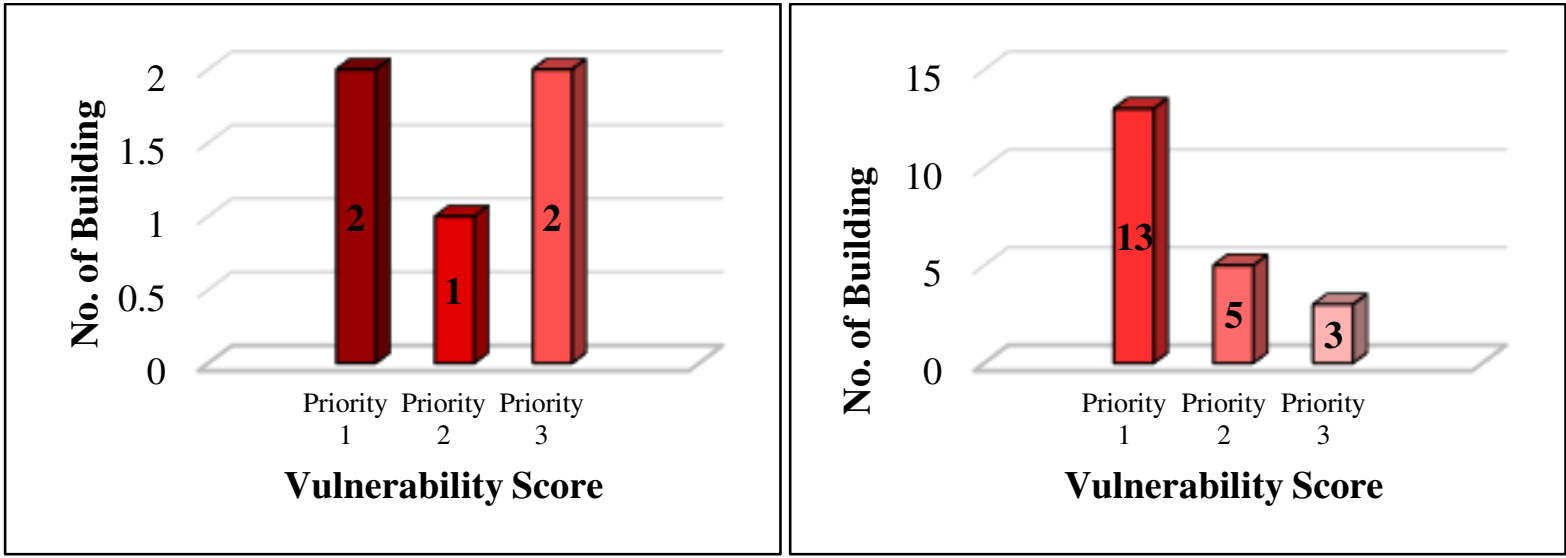

Source: Field survey, 2019

Figure 8: Priority of Very High (left) and High(right) Vulnerable Building (AHP Method)

AHP method is used only for very high vulnerable building and a high vulnerable building in Lalmatia area. Map 9 represents the very high vulnerable building priority and map 10 represent the high vulnerable building priority. It was concluded that (based on AHP results) 5 buildings of very high vulnerable get more priority for retrofitting. And then 21 buildings get priority for retrofitting.

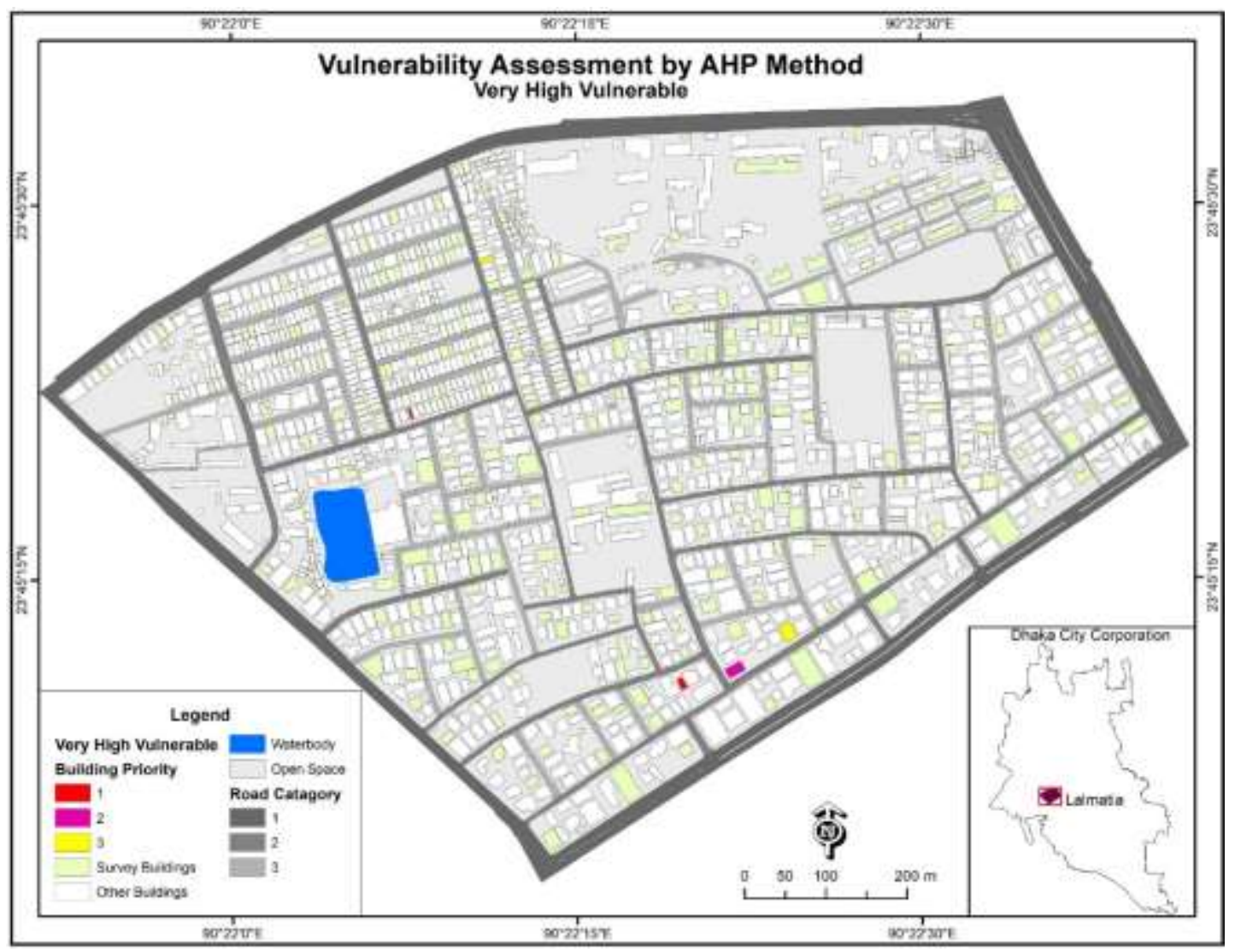

Source: Developed by author, 2019

Map 9: Vulnerability Assessment Map (1) by AHP Method 


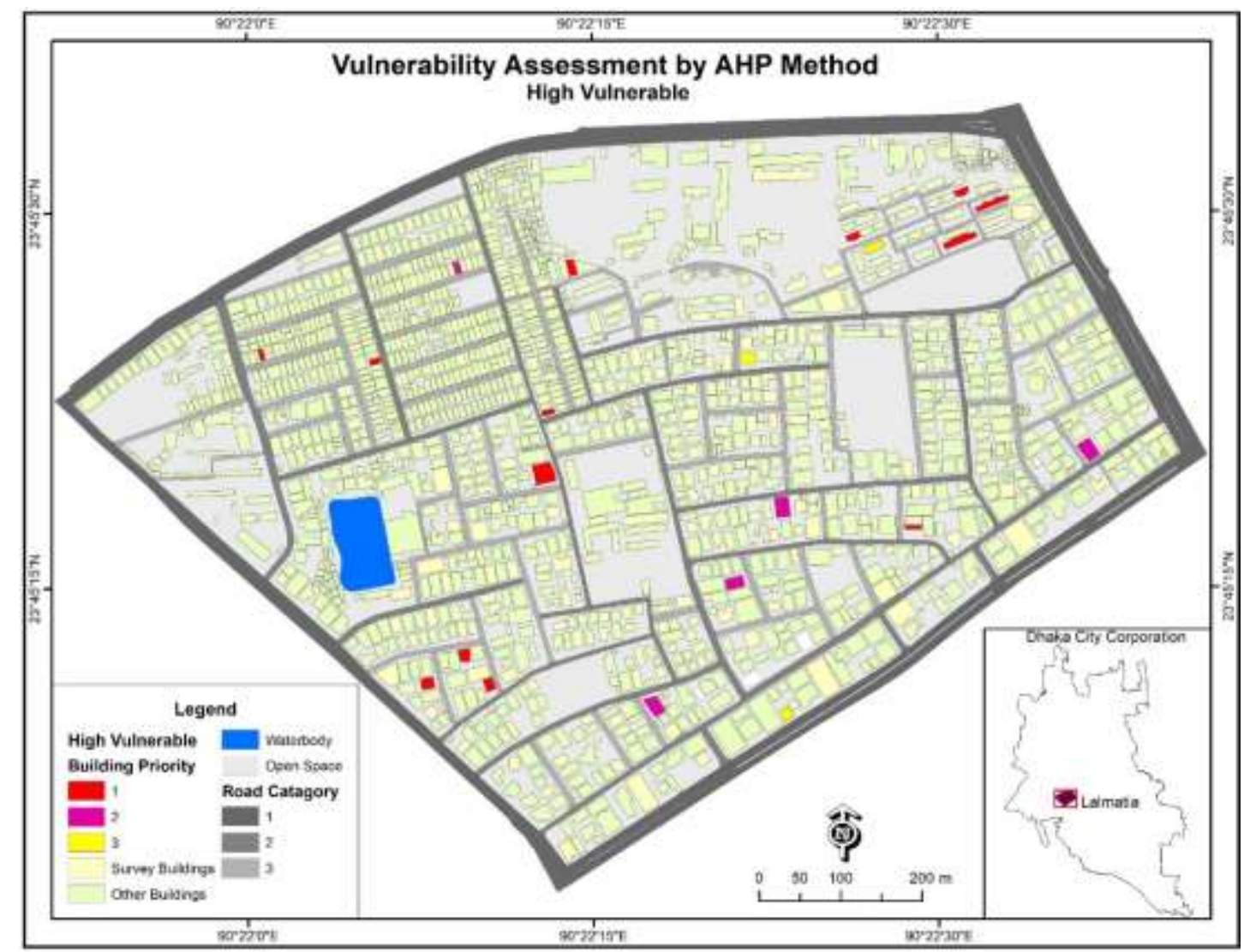

Source: Developed by author, 2019

Map 10: Vulnerability Assessment Map (2) by AHP Method

\section{Conclusion}

Earthquakes is the tremendous threat for the economy, and well-being of the cities, and communities. Thousands of buildings may collapse because of strong earthquake. These strong earthquakes create serious loss of a city that imposed to urban elements. Unplanned urbanization, rapid population growth and density, weak building structure, etc. will produce an uncontrolled condition in most urban areas of the cities, and countries. Other impacts created by the destructive earthquake such as a loss of infrastructure, livelihoods may lead the country to exaggerated misery for a long time. Due to scarcity of digital technology and data, risk zoning map have not been prepared yet for Dhaka city against earthquake stress. The proper analysis of the vulnerable element against earthquake helps to identify risk level of damage. The present study, AHP method has been applied for weighting major building components and the results are also drawn up using GIS with several factors to stimulate earthquakes. Retrofit is one of the important techniques to reduce damage against earthquake hazard. But in the study more people can't be interested as because lacking of information and financial support. The concept of social retrofitting helps to communities and individuals to allow them to recover and react against earthquake hazards. This research will support in planning and development of community as well as developers to exercised reconstruction techniques that was not properly exercised yet. The model that applying in this study will expressly contribute in the vulnerability appraisement and also helps to take mitigation attempts of Dhaka city against earthquake.

\section{References}

Agarwal, P. and Shrikhande, M. (2007). Earthquake resistant design of structures, Prentice-hall, India, 3-41.

Ahmed, S. and Ahmed, H. (2010). Disaster risk and risk mitigation in Dhaka other cities, UNICEF, Dhaka, Bangladesh. 
Ansary, M. A. and Ali, M. (2004). Seismic risk of Dhaka city and role of the insurance community. Insur J Bangladesh 55:5-34

Alam, M. S., Sakib, N. and Mumtaz, M. (2011). Seismic loss assessment of Dhaka for scenario earthquakes using a displacement-based method.

Alam, M. J. B., Ansary, M. A. and Chowdhuary, R. A. (2008). Evaluation of build-ing's vulnerability to earthquake in old part of Sylhet and con-struction safety rules. IUST Int J Eng Sci 19(3):33-43

CDMP. (2009a). Earthquake Contingency Plan for Dhaka City. Dhaka: Comprehensive Disaster Management Program (CDMP), Ministry of Food and Disaster Management, Government of the People's Republic of Bangladesh, Phase 1.

CDMP. (2009b). Risk Assessment of Dhaka, Chittagong and Sylhet City Corporation Area. Dhaka: Comprehensive Disaster Management Program (CDMP), Ministry of Food and Disaster Management, Government of the People's Republic of Bangladesh, Phase 1.

CDMP. (2009c). Vulnerability Assessment of Dhaka, Chittagong and Sylhet City Corporation Area. Dhaka: Comprehensive Disaster Management Program (CDMP), Ministry of Food and Disaster Management, Government of the People's Republic of Bangladesh, Phase 1.

CDMP. (2010). Dhaka city at risk of massive destruction. The daily star, January 24, 2010. Retrieved on 15 October, 2019, from https://www.thedailystar.net/news-detail-123247

Chakrabarty, A., Rahman, M. M. and Ubaura, M. (2020). “Assessment of Emergency Evacuation Preparedness for Seismic Hazard in an Urban Area" in the 17th World Conference on Earthquake Engineering, 17WCEE, Sendai, Japan - September 13th to 18th 2020, pp. 6h-0004, 1-9. Sendai, Japan.

Chen, Y., Kou, G., Ergu, D. and Lin, C. (2016). Pairwise comparison matrix in multiple criteria decisions making. Technological and Economic Development of Economy, 22(5), 738-765.

Choudhury, J. R. (1993). Seismicity in Bangladesh. Bangladesh University of Engineering and Technology (BUET), Dhaka.

Eastman, J.R., Jin, W., Kyem, P.K. and Toledano, J. (1993) Raster Procedures for Multicriteria/Multiobjective Decisions. Photogrammetric Engineering and Remote Sensing, 61, 539-547.

Ferdous, I. and Rahman, M. M. (2015). Citizens at risk from earthquake hazard in Dhaka city: scaling risk factors from household to city region level.

Harker, P. T. and Vargas, L. G. (1987). “The Theory of Ratio Scaled Estimated: Satty’s Analytical Hierarchy Process." Management Science, 33(11): 1385-403. Retrieved October 21, 2020, from https://www.researchgate.net/publication/227445821_The_Theory_of_Ratio_Scale_Estimation_Saaty's_An alytic_Hierarchy_Process

Hossain, N. (2014). 'Street' as accessible open space network in earth-quake recovery planning in unplanned urban areas. Asian J Humanit Soc Sci (AJHSS) 2(4):103-115

Islam, R., Islam, M. N. and Islam, M. N. (2016). Earthquake risks in Bangladesh: causes, vulnerability, preparedness and strategies for mitigation. ARPN Journal of Earth Sciences, 5(2):75-90

Islam, M. S., Hossain, M. T., Ameen, S. F., Hoque, E. and Ahamed, S. (2010). Earthquake induced liquefaction vulnerability of reclaimed areas of Dhaka, Journal of Civil Engineering (IEB), 38(1): 65-80.

Jahan, I., Reja, M. Y. and Ansary, M. (2008). Earthquake evacuation for old Dhaka, Bangladesh. In: 7th International technologies for urban safety of mega cities in Asia. Tsinghua University, Jiang, Beijing, pp: $697-710$

Kamal, A. (2009). Earthquake vulnerability reduction in Dhaka, Syl-het and Chittagong and tsunami/storm vulnerability reduction in coastal cities, Bangladesh. Global platform for disaster risk reduction. Ministry of Food and Disaster Management and Com-prehensive Disaster Management Programme (CDMP), Dhaka 
Khan, A. A. and Hoque, M. A. (2002). Quaternary paleo-geography and geo-hazard scenario of the Bengal delta of Bangladesh. Orient Geogr 46(2):1-16

Li, D., Peng, M. and Shao, Z. (2006). Design and Implementation of Urban Management and Service Grid Based on Spatial Database. In: ASIA GIS international conference, March 9-10, 2006, Johor, Malaysia, pp: 123 131.

Muralidhar, K., Santhanam, R. and Wilson, R. L. (1990). Using the analytic hierarchy process for information system project selection. Inform. Manage., 18: 87-95. Retrieved October 15, 2020, from https://www.sciencedirect.com/science/article/abs/pii/037872069090055M

Paul, B. K. and Bhuiyan, R. H. (2010). Urban earthquake hazard: perceived seis-mic risk and preparedness in Dhaka City, Bangladesh. Disasters 34(2):337-359. https ://doi.org/10.1111/j.1467-7717.2009.01132 .x

Partovi, F. Y. (1992). Determining what to benchmark: An analytic hierarchy process approach. Int. J. Operat. Prod. Manage., 14: 25-39.

Rahman, M. A. (2010). Dhaka in Danger. The daily star, June 10, 2010. Retrieved on 05 November, 2020 from https://www.thedailystar.net/news-detail-142043

Rahman, M. M., Tariq, A. A. and Sharmin. S. (2020). "Planning Intervention in Emergency Evacuation to Minimize Hazard Impact: A Case Study of Old Dhaka and Dhaka Export Processing Zone.” Journal of Earthquake Science and Soil Dynamics Engineering, 3(3), 1-16. http://doi.org/10.5281/zenodo.4305837.

Rashed, T. and Weeks, J. (2003). Assessing vulnerability to earthquake haz-ards through spatial multicriteria analysis of urban areas. Int J Geogr Inf Sci 17(6):547-576. https ://doi.org/10.1080/13658 81031000114071

Reja, M. Y. (2008). Earthquake vulnerability reduction strategies for unplanned urban areas-in the context of Chittagong city. An unpublished B. Aarch thesis, Department of Architecture, BUET

Sarraz, A., Ali, M. K. and Das, D. C. (2015). Seismic vulnerability assessment of existing building stocks at Chandgaon in Chittagong city, Bangla-desh. Am J Civ Eng 3(1):1-8 (ISSN: 2330-8737)

Sattar, M. A., Rana, M. S. and Islam, M. T. (2009). Vulnerability of earthquake disaster in Bangladesh. Bangladesh J Environ Sci 17:13-20 (ISSN 1561-9206)

Saaty, T. L. (1980). The Analytic Hierarchy Process: Planning, priority setting, resource allocation. New York: McGraw Hill.

Sucuoglu, H. and Yazgan, U. (2003). Simple Survey procedures for Seismic Risk Assessment in Urban Building $\begin{array}{lllll}\text { Stocks. } & \text { Retrieved } & \text { October } & 15, & \text { from }\end{array}$ https://www.researchgate.net/publication/242234736_Simple_Survey_Procedures_for_Seismic_Risk_Asses sment_in_Urban_Building_Stocks

UN, (2020). UN World Urbanization Prospects. Retrieved from https://worldpopulationreview.com/worldcities/dhaka-population/. Accessed on 08/06/2020.

UN Habitat, (2020). These are the world's most crowded cities. World Economic Forum. https://www.weforum.org/agenda/2017/05/these-are-the-world-s-mostcrowded- cities/. Accessed 19 July, 2020.

Wu, Y. M., Teng, T. L., Shin, T.C. and Hsiao, N. C. (2003). Relationship between Peak Ground Acceleration, Peak Ground Velocity, and intensity in Taiwan, Bulletin of the seismological Society of America, Vol.93, No. 1, pp. 386-396.

WWW. Wikipedia. Com, (2019). Retrieved October 11, 2019, from https://en.wikipedia.org/wiki/Lalmatia

Ziauddin, N. (2016). A study on earthquake preparedness in schools in Dhaka North City Corporation (Doctoral dissertation, BRAC University). 


\section{Figures}

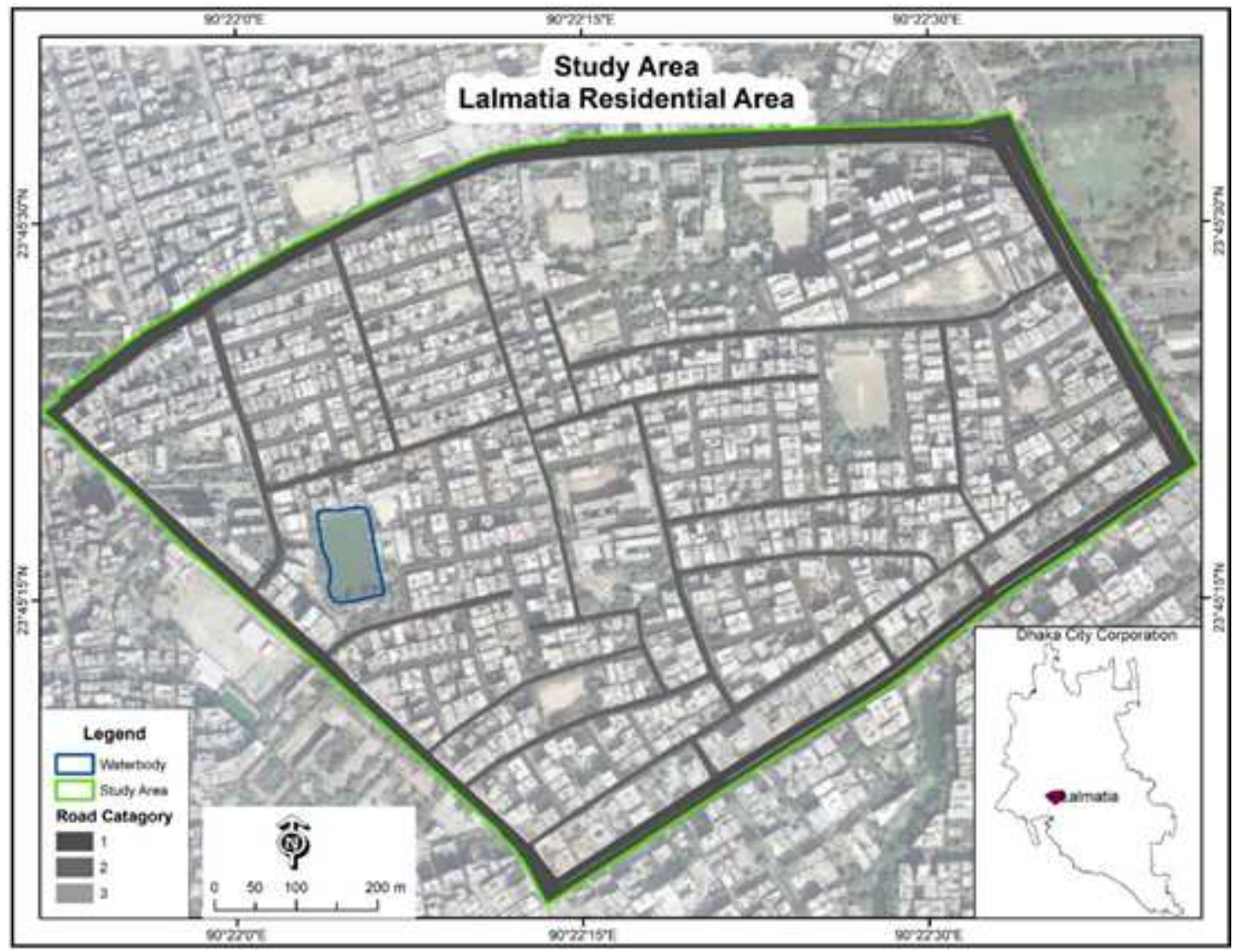

\section{Figure 1}

Study Area Map Note: The designations employed and the presentation of the material on this map do not imply the expression of any opinion whatsoever on the part of Research Square concerning the legal status of any country, territory, city or area or of its authorities, or concerning the delimitation of its frontiers or boundaries. This map has been provided by the authors. 


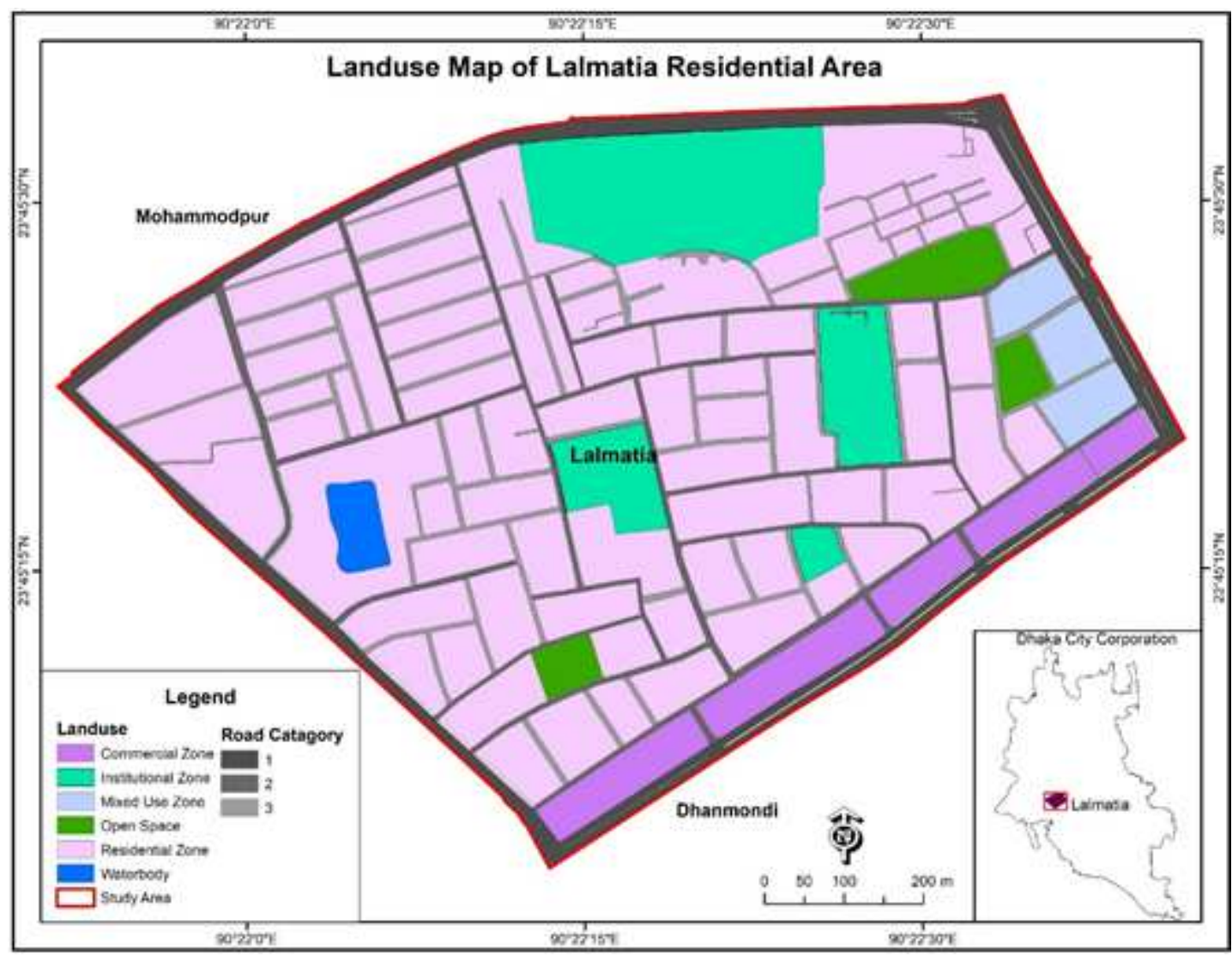

Figure 2

Land use Map of Study Area Note: The designations employed and the presentation of the material on this map do not imply the expression of any opinion whatsoever on the part of Research Square concerning the legal status of any country, territory, city or area or of its authorities, or concerning the delimitation of its frontiers or boundaries. This map has been provided by the authors. 


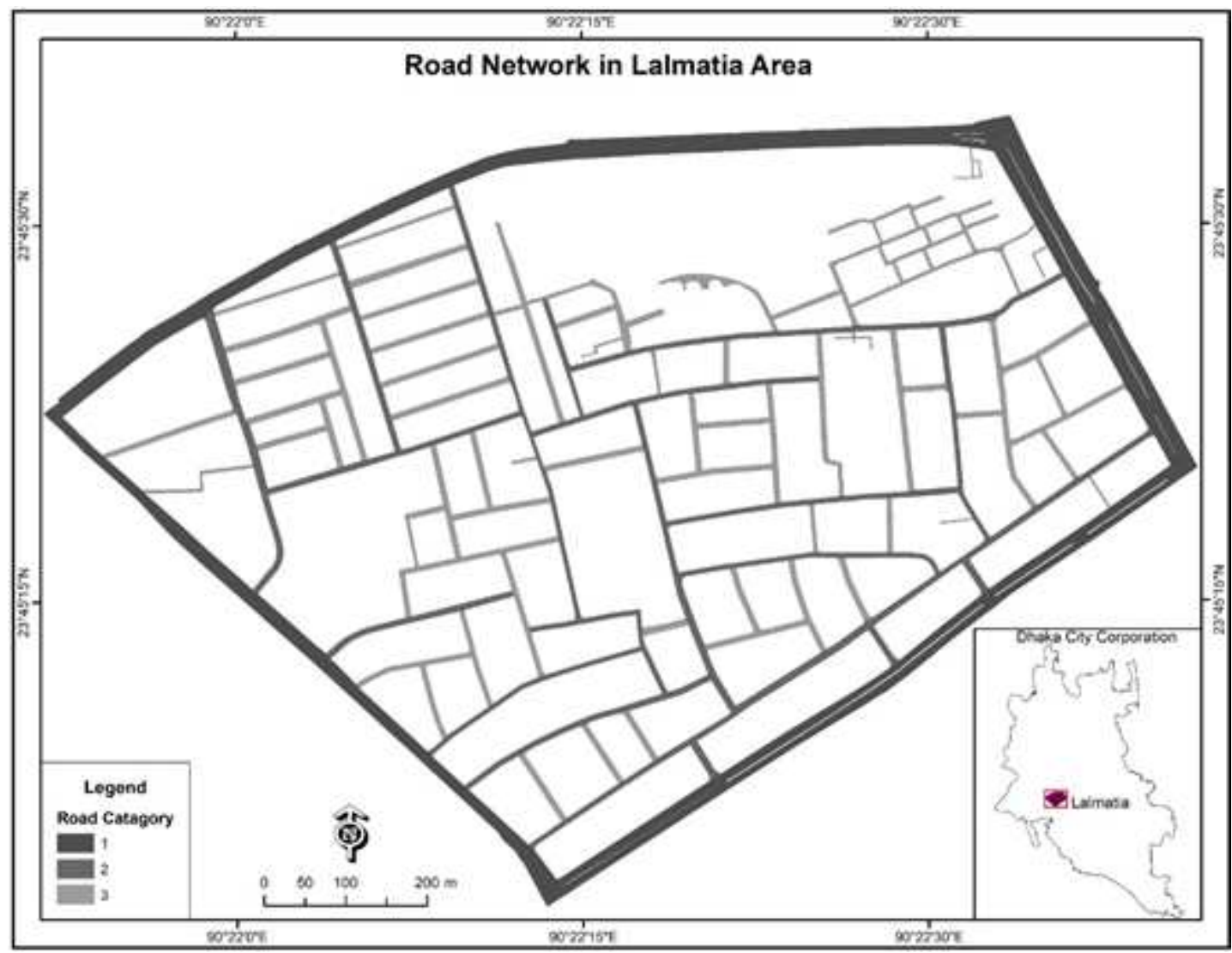

Figure 3

Road Network Map of Lalmatia Area Note: The designations employed and the presentation of the material on this map do not imply the expression of any opinion whatsoever on the part of Research Square concerning the legal status of any country, territory, city or area or of its authorities, or concerning the delimitation of its frontiers or boundaries. This map has been provided by the authors. 


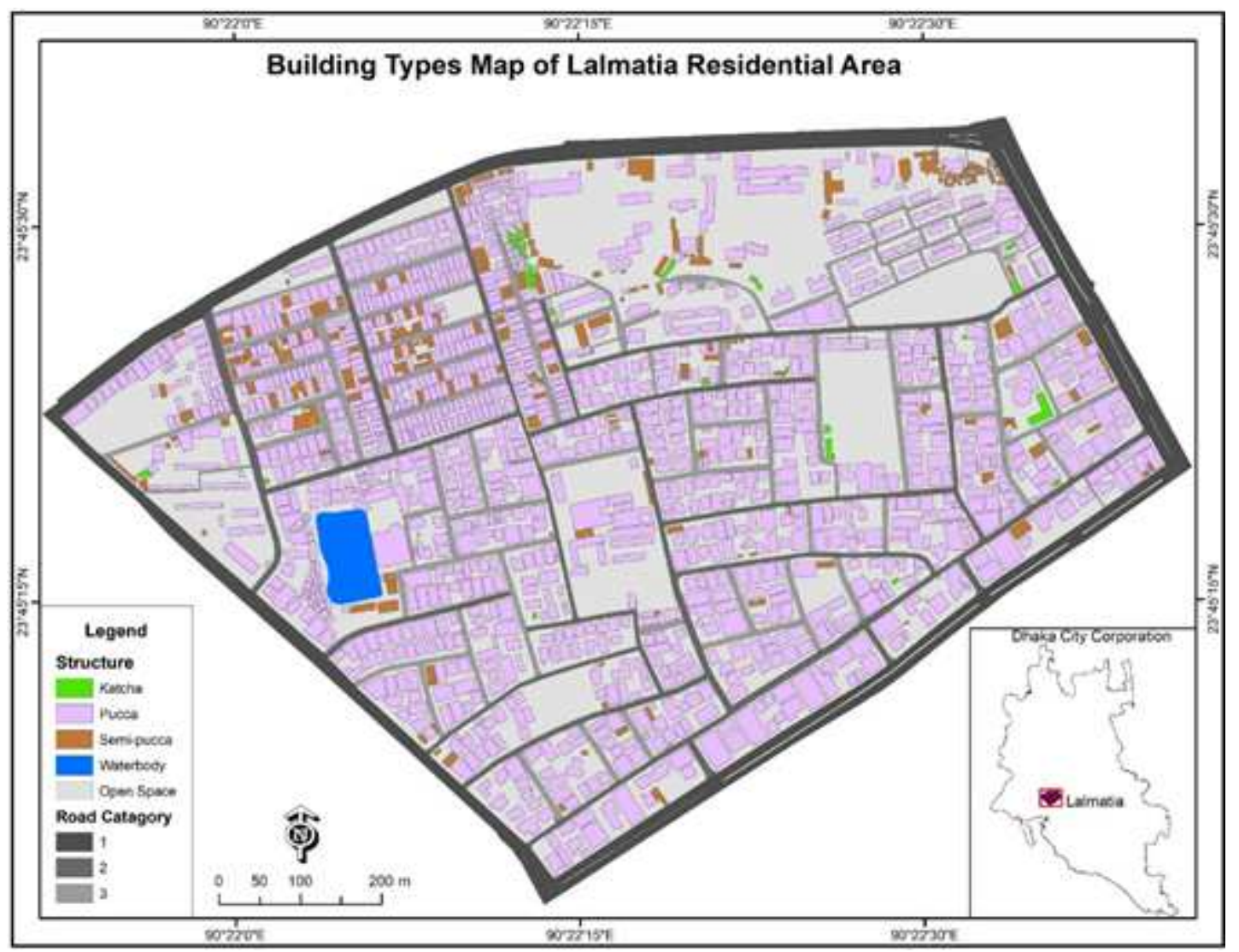

Figure 4

Building Types Map of Study Area Note: The designations employed and the presentation of the material on this map do not imply the expression of any opinion whatsoever on the part of Research Square concerning the legal status of any country, territory, city or area or of its authorities, or concerning the delimitation of its frontiers or boundaries. This map has been provided by the authors. 


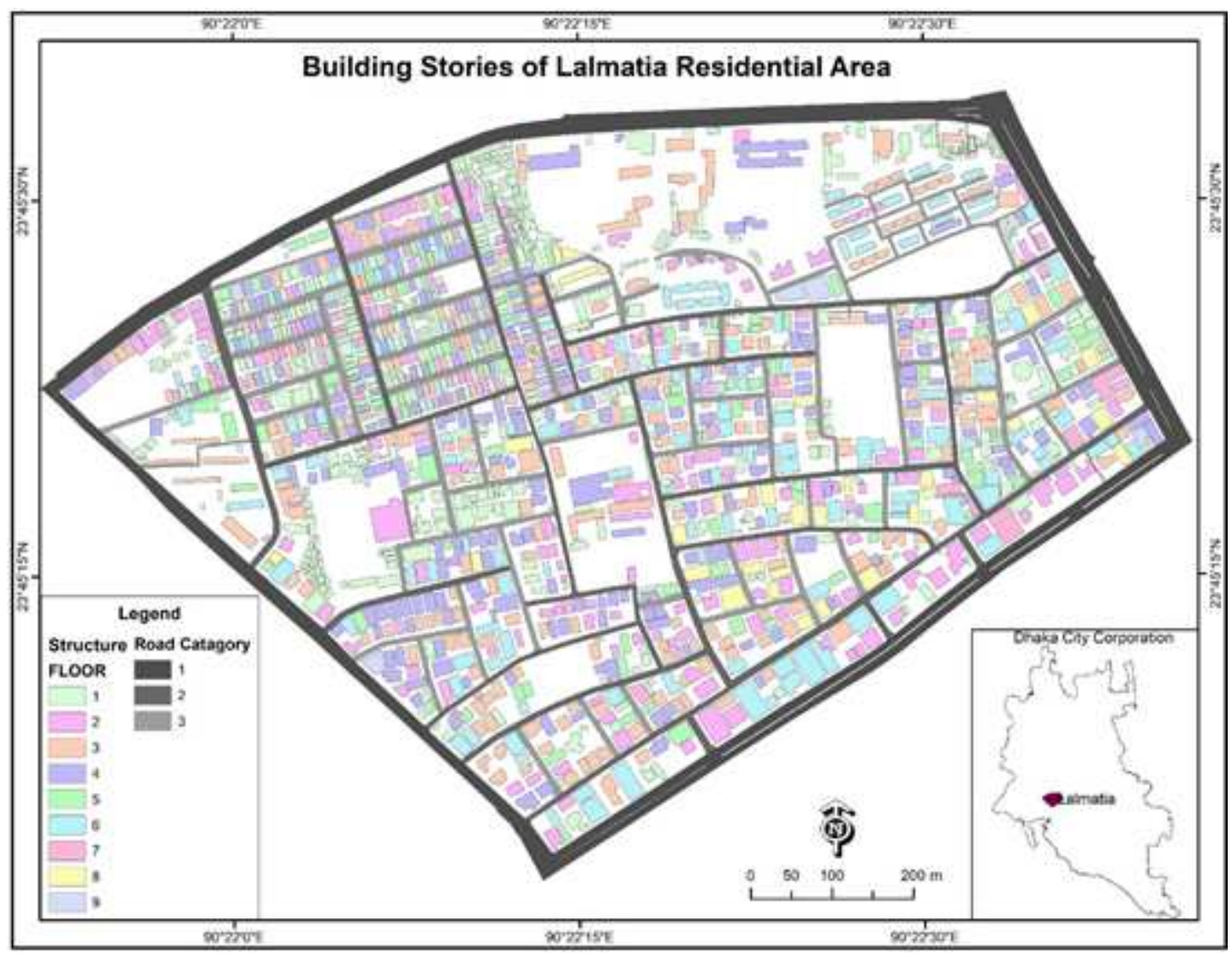

Figure 5

Building Stories Map of Study Area Note: The designations employed and the presentation of the material on this map do not imply the expression of any opinion whatsoever on the part of Research Square concerning the legal status of any country, territory, city or area or of its authorities, or concerning the delimitation of its frontiers or boundaries. This map has been provided by the authors. 


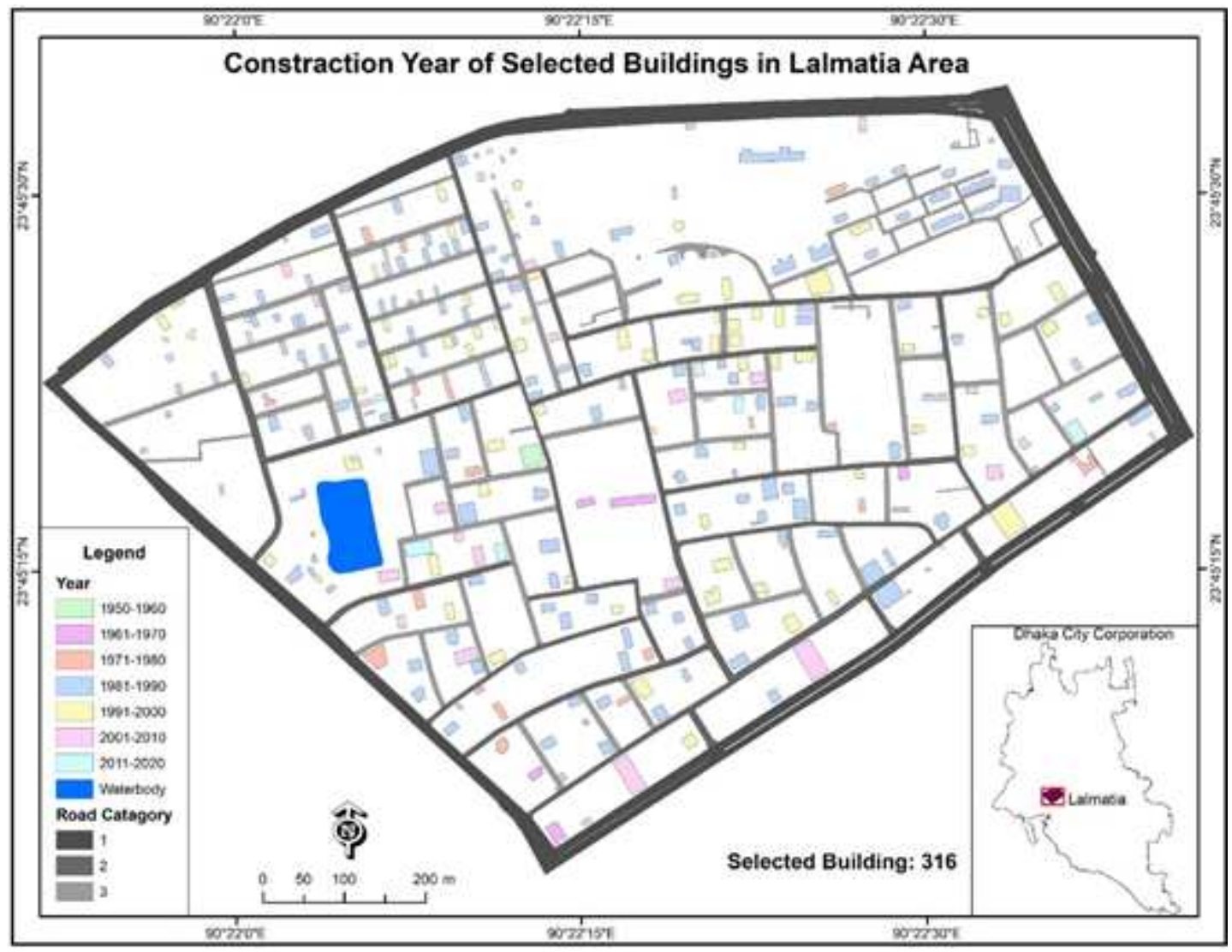

Figure 6

Construction Year Map of Selected Buildings Note: The designations employed and the presentation of the material on this map do not imply the expression of any opinion whatsoever on the part of Research Square concerning the legal status of any country, territory, city or area or of its authorities, or concerning the delimitation of its frontiers or boundaries. This map has been provided by the authors. 


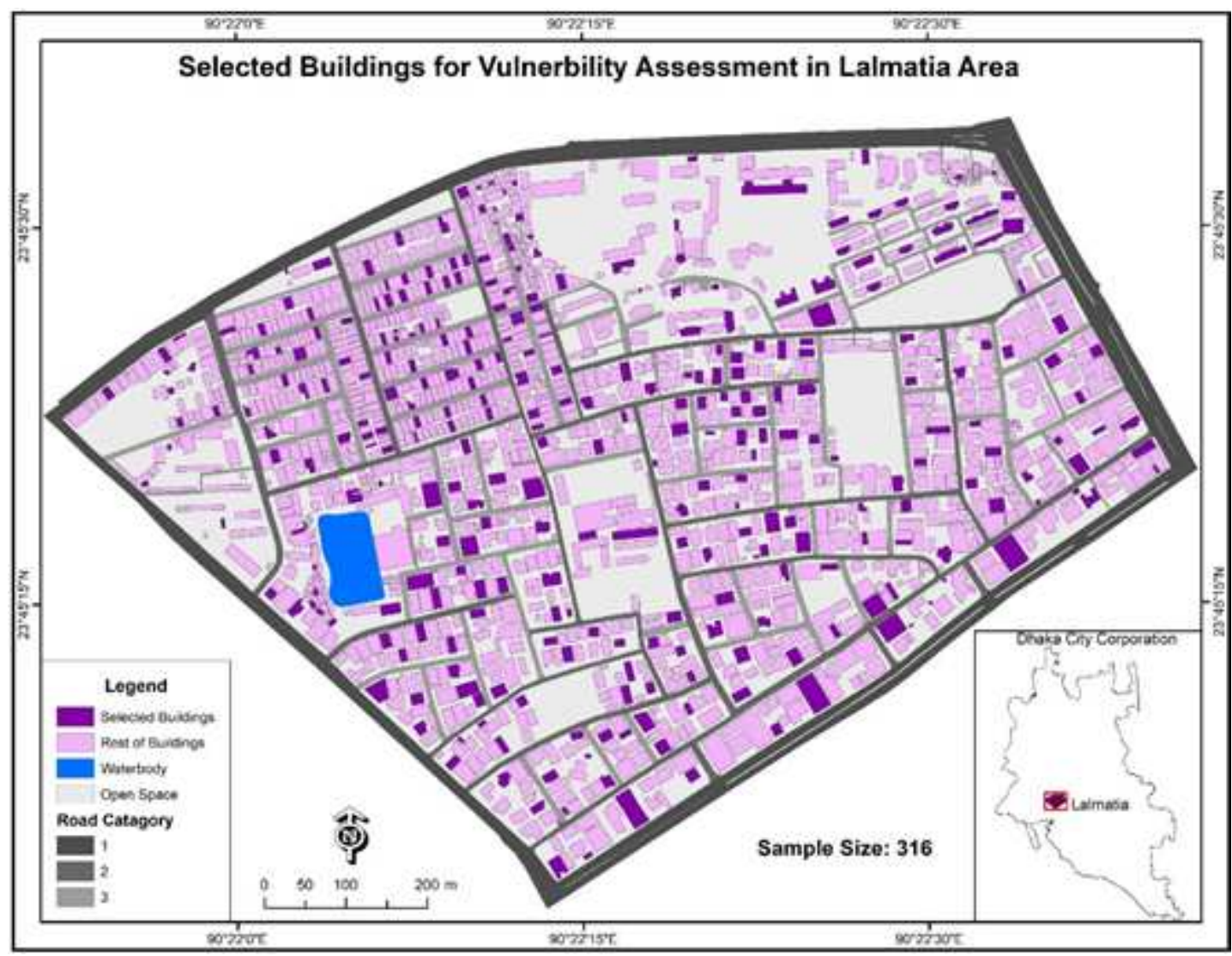

Figure 7

Selected Building for vulnerability Assessment Note: The designations employed and the presentation of the material on this map do not imply the expression of any opinion whatsoever on the part of Research Square concerning the legal status of any country, territory, city or area or of its authorities, or concerning the delimitation of its frontiers or boundaries. This map has been provided by the authors. 


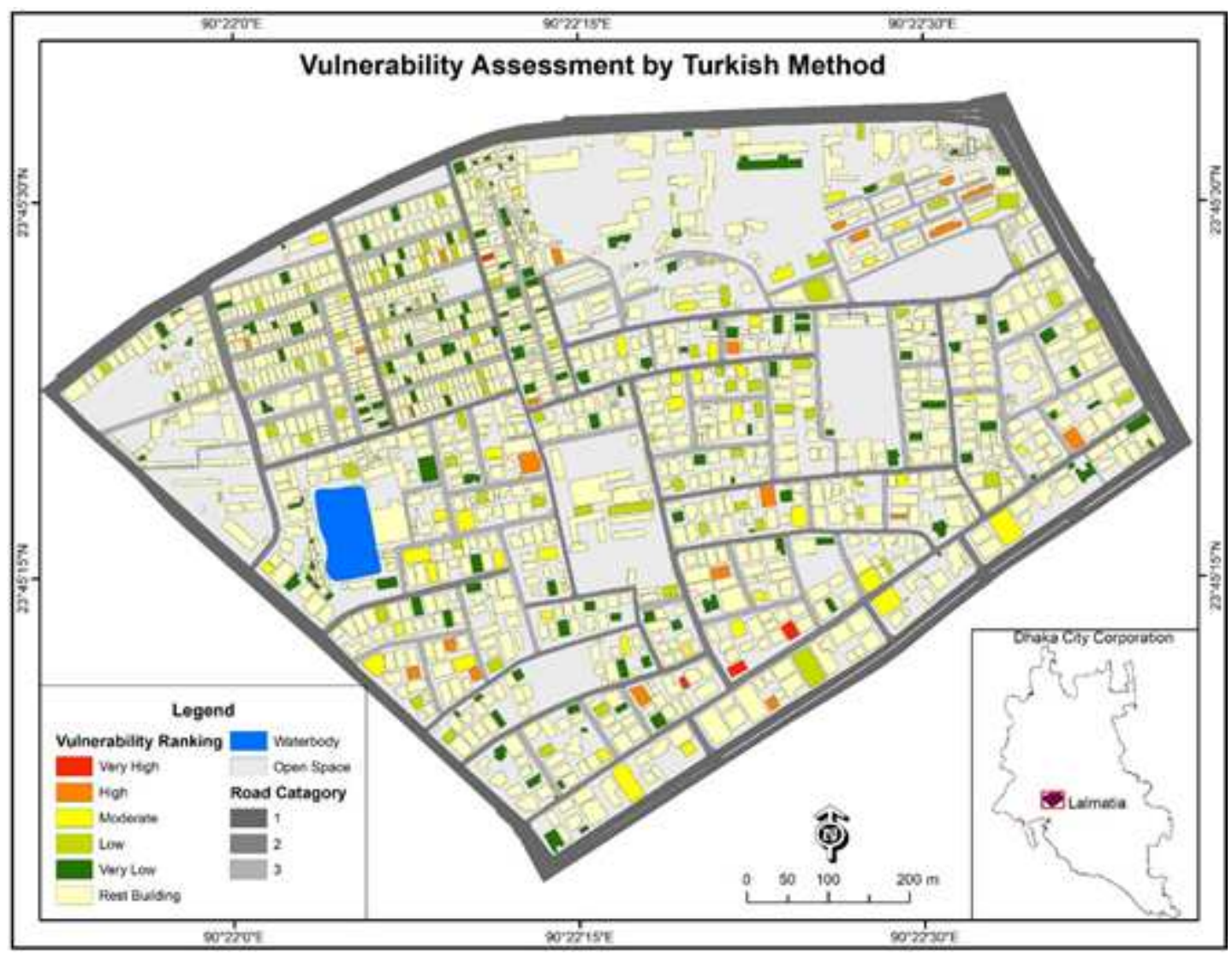

Figure 8

Vulnerability Assessment Map by Turkish Method Note: The designations employed and the presentation of the material on this map do not imply the expression of any opinion whatsoever on the part of Research Square concerning the legal status of any country, territory, city or area or of its authorities, or concerning the delimitation of its frontiers or boundaries. This map has been provided by the authors. 


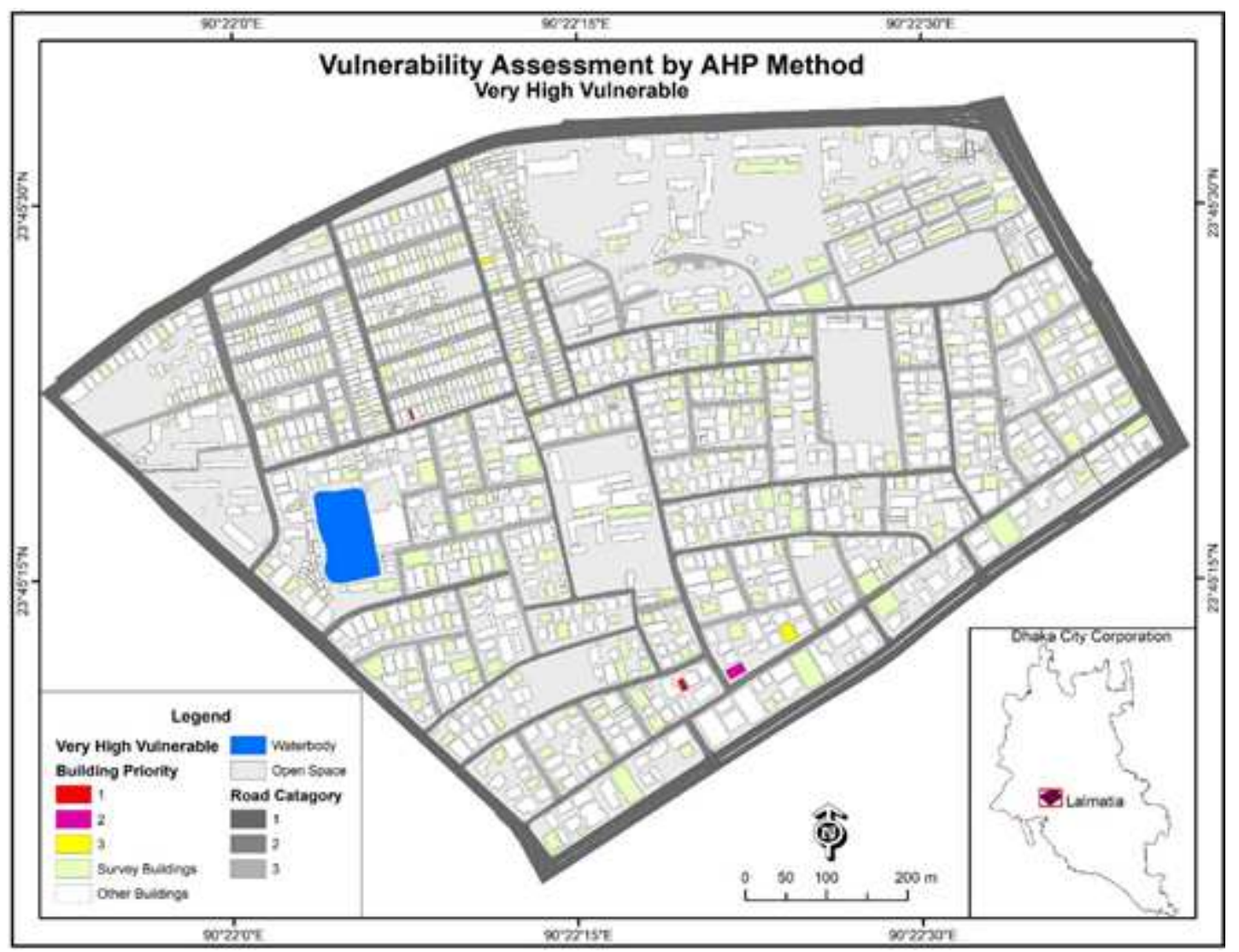

Figure 9

Vulnerability Assessment Map (1) by AHP Method Note: The designations employed and the presentation of the material on this map do not imply the expression of any opinion whatsoever on the part of Research Square concerning the legal status of any country, territory, city or area or of its authorities, or concerning the delimitation of its frontiers or boundaries. This map has been provided by the authors. 


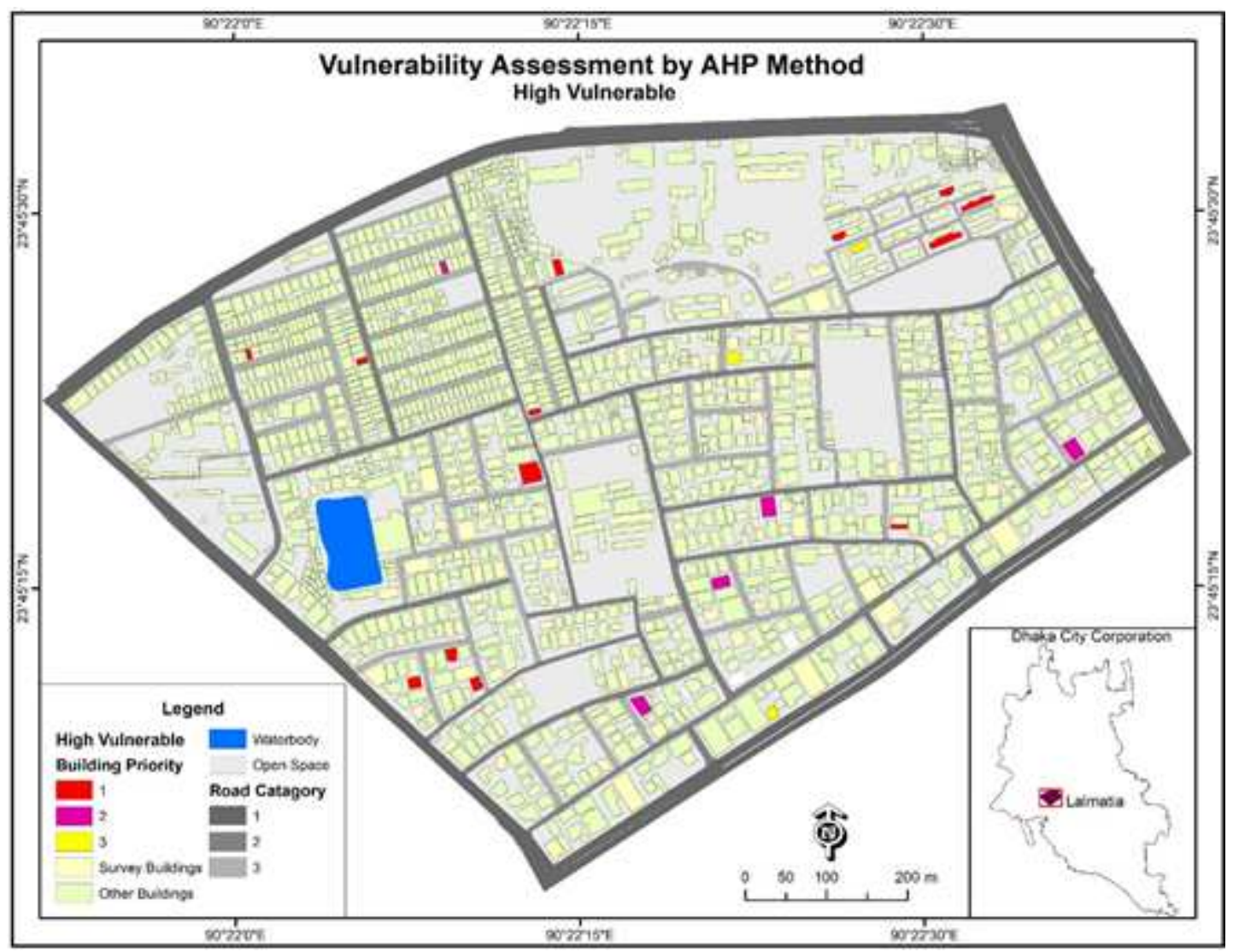

Figure 10

Vulnerability Assessment Map (2) by AHP Method Note: The designations employed and the presentation of the material on this map do not imply the expression of any opinion whatsoever on the part of Research Square concerning the legal status of any country, territory, city or area or of its authorities, or concerning the delimitation of its frontiers or boundaries. This map has been provided by the authors.

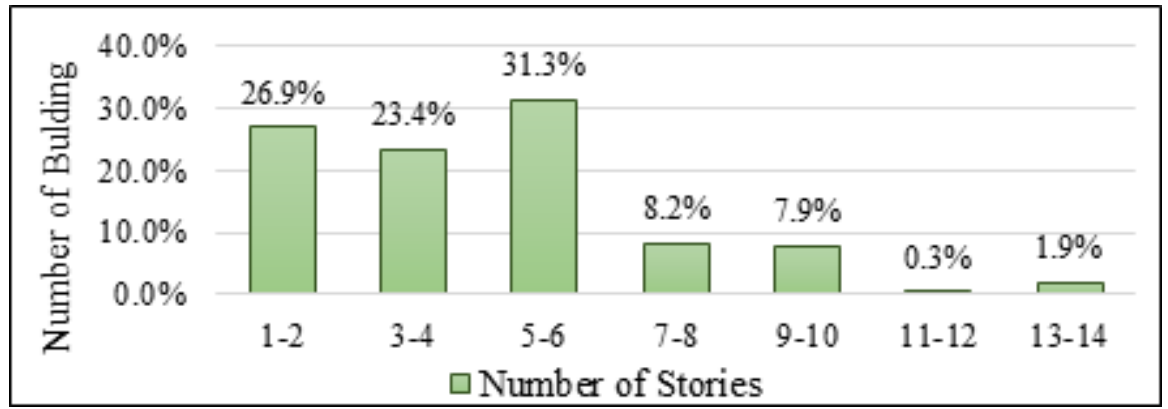

\section{Figure 11}

Number of Stories of Building 


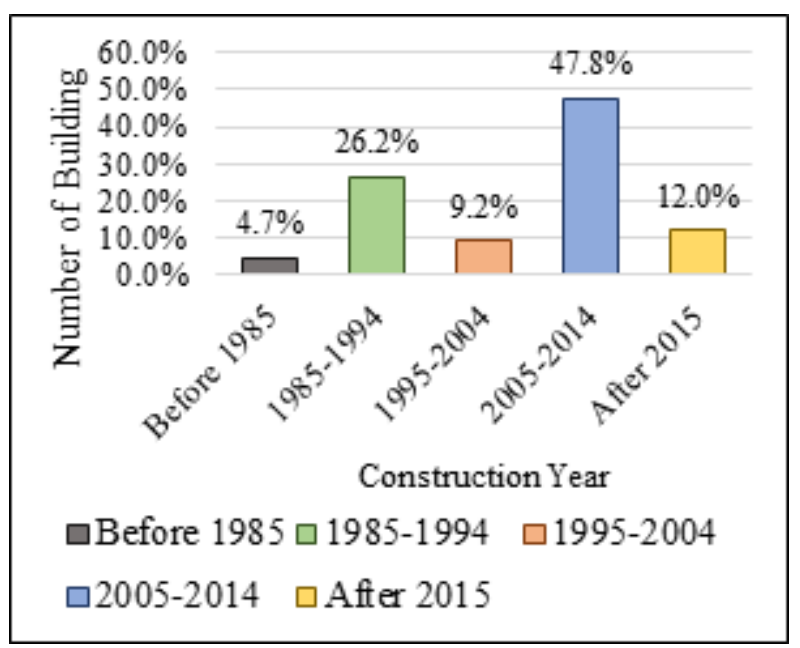

Figure 12

Construction Year of Building

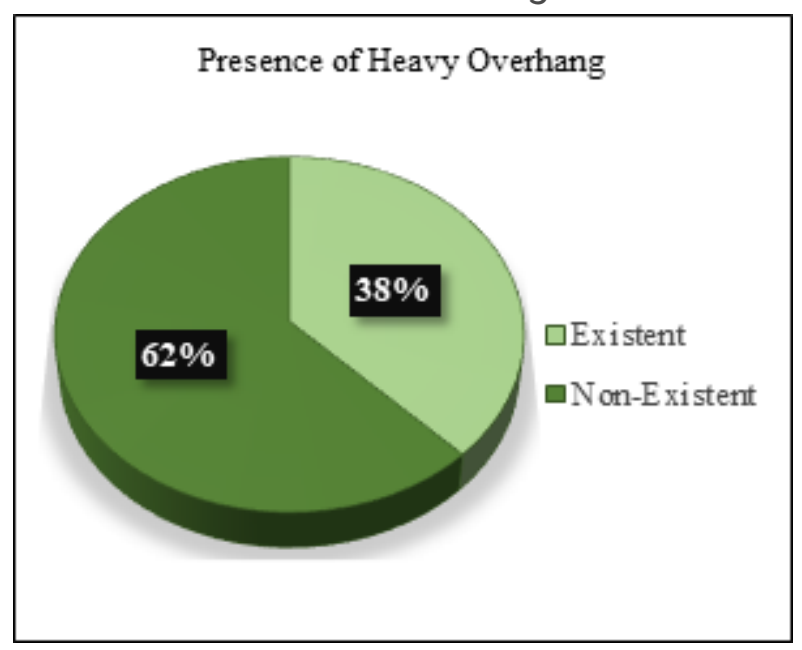

Figure 13

Presence of Heavy Overhang

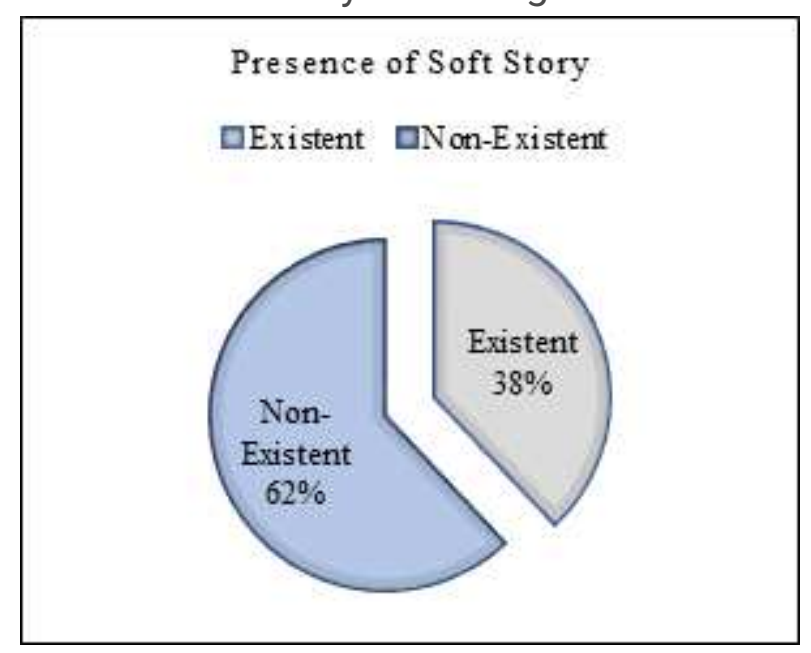

Figure 14 


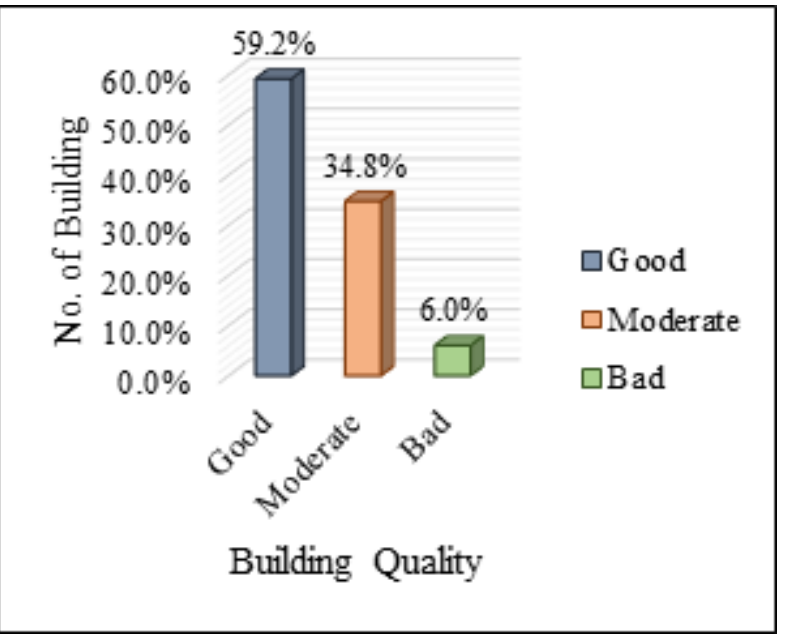

\section{Figure 15}

\section{Apparent Building Quality}

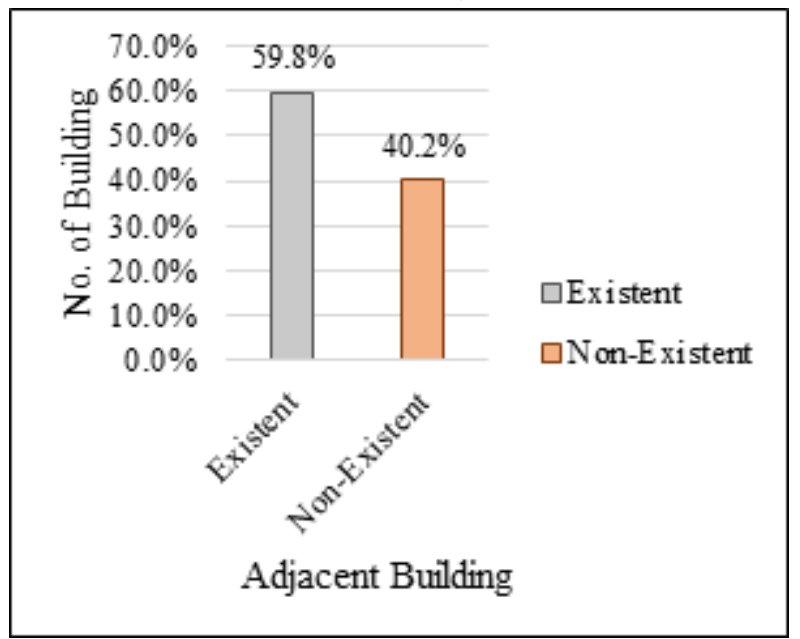

Figure 16

Pounding between Adjacent Building

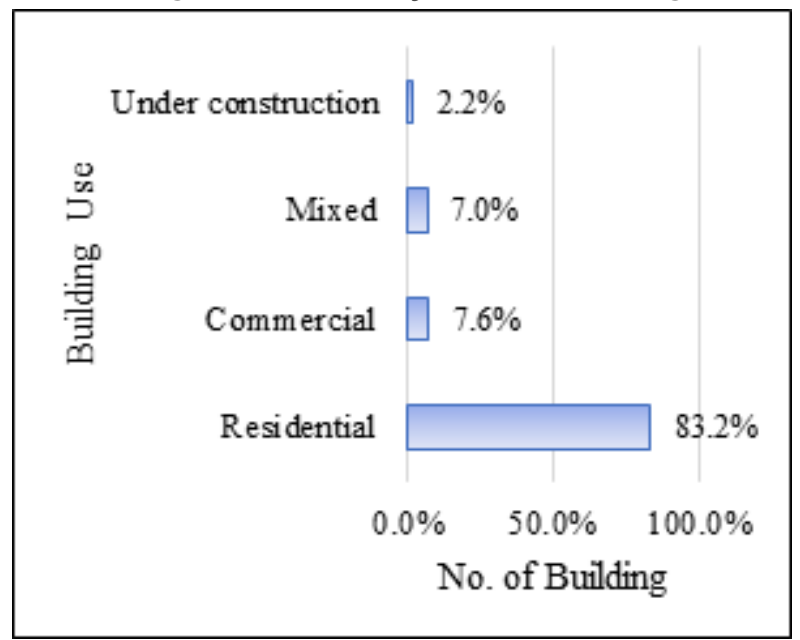


Figure 17

Percentage of Building Use
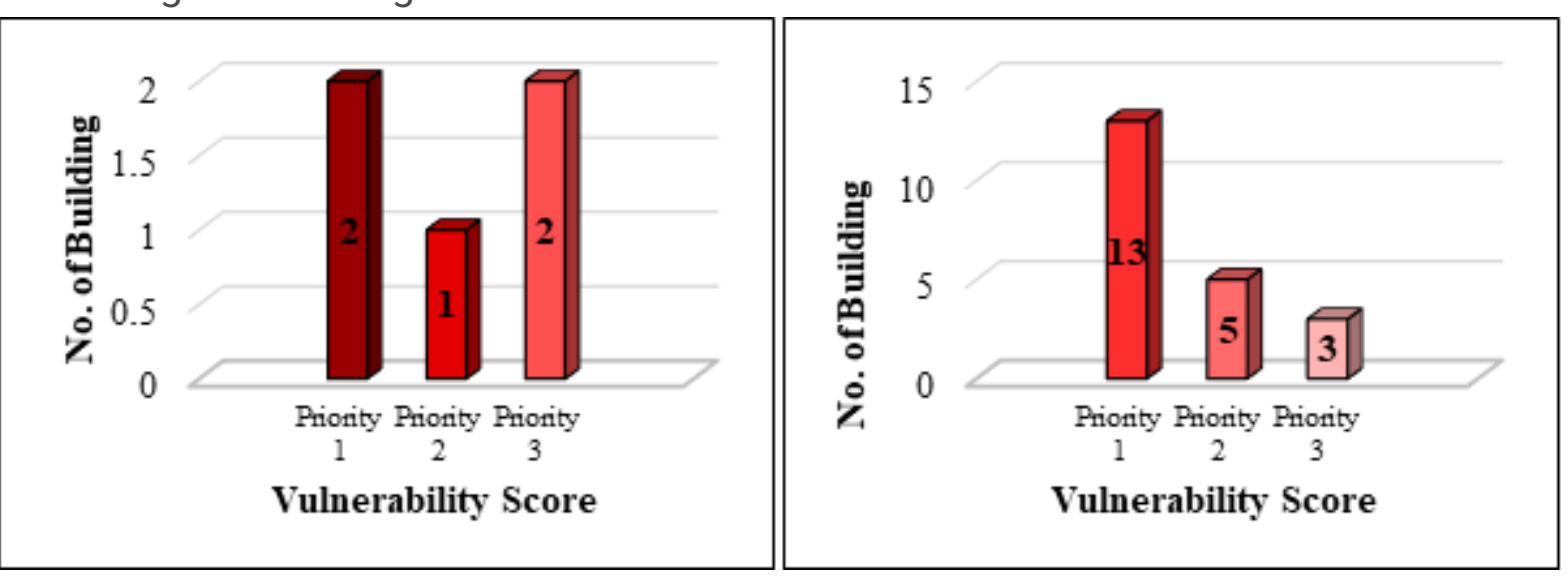

Figure 18

Priority of Very High (left) and High(right) Vulnerable Building (AHP Method) 